\title{
The Distribution of Giant Manta Rays In The Western North Atlantic Ocean Off The Eastern United States
}

Nicholas A. Farmer ( $\nabla$ nick.farmer@noaa.gov )

NOAA/National Marine Fisheries Service

Lance P. Garrison

NOAA/National Marine Fisheries Service, Southeast Fisheries Science Center

Calusa Horn

NOAA/National Marine Fisheries Service

Margaret Miller

NOAA/National Marine Fisheries Service

Timothy Gowan

Florida Fish and Wildlife Research Institute

Robert D. Kenney

University of Rhode Island

Michelle Vukovich

Normandeau Associates Inc

Julia Robinson Willmott

Normandeau Associates Inc

Jessica Pate

Marine Megafauna Foundation

D. Harry Webb

Georgia Aquarium

Timothy J. Mullican

Georgia Aquarium

Joshua D. Stewart

NOAA/National Marine Fisheries Service, Southwest Fisheries Science Center

Kim Bassos-Hull

Mote Marine Laboratory

Christian Jones

NOAA/National Marine Fisheries Service, Southeast Fisheries Science Center

Delaney Adams

Western Washington University

Stephen Kajiura 
Florida Atlantic University

Jordan Waldron

Florida Atlantic University

\section{Research Article}

Keywords: giant, sightings, species distribution modeling

Posted Date: July 15th, 2021

DOl: https://doi.org/10.21203/rs.3.rs-677529/v1

License: (c) (1) This work is licensed under a Creative Commons Attribution 4.0 International License. Read Full License 


\section{Abstract}

In 2018, the giant manta ray (Manta birostris) was listed as threatened under the U.S. Endangered Species Act. We integrated decades of sightings and survey effort data from multiple sources in a comprehensive species distribution modeling (SDM) framework to evaluate the distribution of giant manta rays off the eastern United States, including the Gulf of Mexico. Manta rays were most commonly detected at productive nearshore and shelf-edge upwelling zones at surface thermal frontal boundaries within a temperature range of approximately $15-30^{\circ} \mathrm{C}$. SDMs predicted high nearshore concentrations off Northeast Florida during April, with the distribution extending northward along the shelf-edge as temperatures warm, leading to higher occurrences north of Cape Hatteras, North Carolina from June to October, and then south of Savannah, Georgia from November to March as temperatures cool. In the Gulf of Mexico, the highest nearshore concentrations were predicted near the Mississippi River delta from April to June and again from October to November. SDM predictions will allow resource managers to more effectively protect manta rays from fisheries bycatch, boat strikes, oil and gas activities, contaminants and pollutants, and other threats.

\section{Introduction}

Manta rays are filter-feeding rays in the family Mobulidae (Poortvliet et al. 2015), characterized by a terminal mouth, diamond-shaped bodies with wing-like pectoral fins, and long cephalic fins (Romanov 2010). The taxonomic history of the genus Manta is complex (Herman et al. 2000; Adnet et al. 2012; Couturier et al. 2012; Naylor et al. 2012b; Kitchen-Wheeler 2013; Paig-Tran et al. 2013; Aschliman, 2014; Poortvliet et al. 2015), with more recent studies supporting splitting the Manta genus into two species: $M$. birostris and M. alfredi (Marshall et al. 2009), and synonymizing the genus Manta with the genus Mobula (White et al. 2017). Of the two manta species, only giant manta rays (Manta birostris) occur in the western North Atlantic Ocean. In 2018, giant manta rays were listed as a threatened species by the U.S. National Oceanic and Atmospheric Administration (NOAA) under the U.S. Endangered Species Act (ESA) due to significant declines in abundance from overutilization in the Indo-Pacific and eastern Pacific portion of its range, exacerbated by a lack of effective management measures to control this threat and the species' inherent vulnerability to depletion due to its slow growth, late maturation, and low reproductive output (NOAA 2018).

Effective conservation and management of highly mobile marine species requires an understanding of the environmental drivers of their spatio-temporal distribution. The lack of available data to identify physical or biological features essential to the conservation of giant manta rays within areas under U.S. jurisdiction resulted in a "not prudent" determination for the designation of critical habitat under the ESA (NOAA 2019). Significant data gaps were identified regarding giant manta ray movements, foraging areas, aggregation sites and nursery grounds. Although the species is globally distributed, individual manta ray populations are highly fragmented (CITES 2013). Giant manta rays appear to conduct seasonal migrations following prey abundance (Clark 2010; Burgess 2017; Beale et al. 2019), with prey including planktonic and micronektonic organisms such as euphausiids, copepods, mysids, decapod 
larvae and shrimp, and fish spawn (Bertolini 1933; Bigelow and Schroeder 1953; Carpenter and Niem 2001; Rohner et al. 2017a; Stewart et al. 2017). Many international studies have documented seasonal sighting patterns associated with movements of prey, current circulation and tidal patterns, seasonal upwelling, seawater temperature, and possibly mating behavior (Couturier et al. 2012; De Boer et al. 2015; Armstrong et al. 2016; Hacohen-Domené et al. 2017). For example, off the northern Yucatán peninsula, Hacohen-Domené et al. (2017) found that manta ray occurrence was seasonal and associated with high sea surface temperatures $\left(>27^{\circ} \mathrm{C}\right)$, high primary productivity $\left(4,500 \mathrm{mg} \mathrm{C} \cdot \mathrm{m}^{-2} \cdot \mathrm{day}^{-1}\right)$, shallow waters $(<$ $10 \mathrm{~m})$, relatively short distances to shore $(<50 \mathrm{~km})$, and shallow bottom slope $\left(<0.5^{\circ}\right)$.

Within the northern hemisphere, giant manta rays have been documented as far north as southern California and New Jersey on the United States west and east coasts, respectively; Mutsu Bay, Aomori, Japan; the Sinai Peninsula and Arabian Sea, Egypt; and the Azores Islands (Gudger 1922; Kashiwagi et al. 2010; Moore 2012; CITES 2013). In the southern hemisphere, the species occurs as far south as Peru, Uruguay, South Africa, Tasmania (Australia), New Zealand and French Polynesia (Mourier 2012; CITES 2013). Despite this large range, sightings are uncommon outside of regional hotspots that include the Similan Islands (Thailand); Raja Ampat (Indonesia); northeast North Island (New Zealand); Kona, Hawaii (USA); Laje de Santos Marine Park (Brazil); Isla de la Plata (Ecuador); Ogasawara Islands (Japan); Isla Margarita and Puerto la Cruz (Venezuela); and northern coast of the Yucatán Peninsula, Isla Holbox, Revillagigedo Islands, and Bahia de Banderas (Mexico) (Notarbartolo-di-Sciara and Hillyer 1989; Homma et al. 1999; Duffy and Abbott 2003; Luiz et al. 2009; Clark 2010; Kashiwagi et al. 2010; Marshall et al. 2011a; Stewart et al. 2016; Hacohen-Domené et al. 2017). Off the eastern United States (EUS), defined here as the U.S. exclusive economic zone from Maine to Texas, regular manta ray sightings have been reported at Flower Garden Banks National Marine Sanctuary (FGBNMS) in the Gulf of Mexico (Childs 2001; Stewart et al. 2018) and along Florida's eastern coast (Pate \& Marshall 2020; Webb et al. unpublished data).

The spatio-temporal distribution of giant manta rays in the EUS is poorly understood, although recent advances have characterized habitat suitability and regional hotspots for manta rays in the Gulf of Mexico and Caribbean (Garzon et al. 2020). To address this data gap, we integrated decades of sightings and survey effort data from numerous sources in a comprehensive species distribution modeling (SDM) framework. A putative species or subspecies of the giant manta ray has been suggested (referred to as M. cf. birostris; Marshall et al. 2009, Hosegood et al. 2020) to occur off southeastern Florida (Pate and Marshall 2020), FGBNMS (Stewart et al. 2018), the Yucatan peninsula (Hinojosa-Alvarez et al. 2016), and Brazil (Bucair et al. 2021). Given the lack of easily recognized visually distinguishing characteristics, our analysis of manta ray distributions in the EUS should be considered inclusive of $M$. cf. birostris and we refer to this aggregate as 'manta rays' throughout. Although manta rays are not targeted by fisheries in the United States, they may be adversely affected by commercial and recreational fishing bycatch, boat strikes, oil and gas activities, contaminants and pollutants, military activities, and climate change (Stewart et al. 2018a; Pate \& Marshall 2020). A more comprehensive understanding of the distribution of the species would allow managers to more effectively protect mantas from these threats. Understanding 
the environmental drivers of their distribution will allow researchers to more efficiently locate these rare animals for scientific study and potentially predict changes in their distribution under climate change scenarios. Finally, SDMs provide managers a better understanding of the factors influencing giant manta ray movements and habitat use, facilitating more effective timing and coordination of conservation efforts.

\section{Methods}

\section{Sources and Survey Data Processing}

Few dedicated surveys for mantas exist in the EUS; however, due to their large size and distinct appearance, they are often observed and recorded during visual aerial surveys that target marine mammals and sea turtles. To better characterize the distribution of mantas in EUS waters, we assembled a comprehensive geographic information system (GIS) database of manta sightings from peer-reviewed literature, survey databases, gray literature reports, and anecdotal sources (e.g., social media, press reports, personal communications). A comprehensive internet search revealed many photos and videos of manta sightings from news outlets and citizen scientists on Instagram, Facebook, YouTube, and Twitter. Publishers of sightings content were then contacted and asked about manta size, location, and date of the sighting. Additional anecdotal information was received through NOAA's reporting email: manta.ray@noaa.gov.

Photos and informal interviews with observers were used to assess the reliability of identification records from surveys and grey literature (D. Adams, unpublished data). Observers suggested possible misidentification of mantas with Mobula tarapacana and M. mobular in North Atlantic Right Whale Consortium (NARWC) aerial surveys north of Cape Hatteras, North Carolina (T. Pusser, pers. comm. to C. Jones). On Southeast Fisheries Science Center (SEFSC) surveys, M. tarapacana were identified to species; however, there was a potential for misidentification of $M$. mobular. To avoid overestimation of manta ray abundance, sightings and effort north of $35^{\circ} \mathrm{N}$ were excluded from the SEFSC and NARWC surveys for species distribution modeling efforts. All purported "manta ray" sightings from both surveys were retained for external validation of the models and for detection function development, given similarities in size between mantas and other large mobulid species. Correct identification was confirmed north of $35^{\circ} \mathrm{N}$ for New York State Energy Research and Development (NYSERDA) surveys as discussed below. SEFSC and NARWC observers did not note similar concerns south of Cape Hatteras. Photo archives and discussions with Georgia Aquarium observers verified $>1500$ mantas off northeastern Florida. A supplemental review of photographic archives collected during Normandeau Associates Bureau of Ocean Energy Management aerial surveys suggested that $<30 \%$ of SEFSC and NARWC aerial survey "manta ray" sightings from North Carolina to South Carolina might be M. mobular (J. Robinson Willmott and C. Horn, unpublished data). Similarly, a supplemental review of photographic archives from Florida Fish and Wildlife Research Institute (FWRI) North Atlantic right whale aerial surveys flown in winter (December-March) from approximately Savannah, Georgia $\left(31.93^{\circ} \mathrm{N}\right)$ to Cape Canaveral, Florida $\left(28.67^{\circ} \mathrm{N}\right)$ revealed 3 of $85(3.5 \%)$ sightings identified as "manta rays" were M. mobular, with no recorded 
sightings of $M$. tarapacana, suggesting a very low potential misidentification rate with other large mobulids for aerial surveys conducted in that region (J. Jakush, pers. comm.). Photographs and videos were used to verify the accuracy of species identification from anecdotal sources.

\section{Southeast Fisheries Science Center (SEFSC) Aerial Surveys}

Aerial line-transect surveys were conducted along the U.S. Gulf of Mexico and Atlantic coast between Texas and New Jersey by the National Marine Fisheries Service SEFSC between 2010 and 2019. These aerial surveys were primarily designed to estimate the abundance of marine mammals and sea turtles in continental shelf waters. Surveys were conducted once per season in the Gulf of Mexico during 20112012 as part of the Natural Resources Damage Assessment associated with the Deepwater Horizon oil spill (SEFSC-GOMNRDA, Garrison 2017), and three surveys of the Gulf of Mexico were conducted during 2017-2018 as part of the Gulf of Mexico Marine Assessment Program for Protected Species (SEFSCGoMMAPPS; Garrison et al. 2021) and covered the continental shelf and the inner continental slope from Texas to southwest Florida. Along the U.S. Atlantic coast, similar surveys were flown covering all four seasons between 2010-2019. These surveys were conducted as part of the Atlantic Marine Assessment Program for Protected Species (SEFSC-AMAPPS; Palka et al. 2017) and covered the continental shelf and the inner continental slope from southeast Florida to New Jersey.

All SEFSC surveys were conducted aboard a DeHavilland DHC-6 Twin Otter and were flown at an altitude of $182 \mathrm{~m}$ and an airspeed of $185 \mathrm{~km} / \mathrm{hr}$. Surveys were typically flown during favorable sighting conditions at Beaufort sea states $\leq 4$ (surface winds $<12$ knots). Two independent teams of visual observers searched for marine mammals and sea turtles from directly beneath the aircraft out to a perpendicular distance of approximately $600 \mathrm{~m}$ from the trackline. The aircraft included bubble windows and a belly window, allowing the area underneath the trackline to be observed. Team 1 (forward) consisted of two bubble window observers, each stationed at one side of the aircraft and one data recorder. Team 2 (aft) consisted of one observer on the right bubble and one on the belly window, in addition to a data recorder. The two-team configuration allows for the estimation of detection probability on the trackline following approaches described in Laake and Borchers (2004). The aircraft location, survey effort status, and viewing conditions (e.g., sea state, glare, visibility) were recorded every 10 seconds using a data-logging program. Observers updated viewing conditions whenever needed and generally after turns into a new trackline. Upon sighting a marine mammal, sea turtle, or other target of interest (including manta rays), the observer measured the angle from the vertical to the animal (or group) using a digital clinometer. This sighting angle, $\theta$, was converted to the perpendicular sighting distance from the trackline $(P S D)$ by PSD $=\tan (\theta) \times$ Altitude. While manta rays were not the primary focus of the surveys, observers were instructed to record all large fish sightings (including rays, sharks, tuna, etc.) and collected angles for estimating sighting distances wherever possible.

Sightings and effort data were combined for all SEFSC aerial surveys. An initial investigation of the distribution of PSDs indicated a reduction in the number of sightings very close to the trackline for Team 2 , and therefore Team 2 data were truncated at the minimum distance that manta rays were observed 
and sightings between 0 and $3.2 \mathrm{~m}$ were removed from the analysis. Sighting angles were determined for both observer teams based on side (i.e., left, right) and position (e.g., belly, bubble) of each recorded sighting. Because the survey was not specifically designed for mantas, sighted individuals were not assigned unique identifiers. Using forward team sightings as a reference, aft team sightings were matched to forward team sightings when an equal number of animals were recorded by the aft team within 15 seconds, on the same side of the aircraft, and with an angle difference of $<15$ degrees. Any sightings where the aft team could not have seen the animal due to the sighting angle recorded by the forward team were eliminated from the detection function analysis. Based on histograms and quantiles of sightings distance, the right truncation distance was set at $300 \mathrm{~m}$ (Supplemental File 1).

Effective search effort for mantas was determined in a mark-recapture distance sampling framework using package ' $m r d s$ ' in R (Laake et al. 2020) for "On Effort" sightings by the forward and aft survey teams (Supplemental File 1). The probability of detection and effective area searched were derived using the independent-observer approach assuming point independence (Laake \& Borchers 2004, Laake et al. 2020). A hazard rate MRDS (Laake et al. 2020) model was selected by Akaike's Information Criterion (AIC; Akaike 1973). Fitting of the detection model considered all possible permutations of covariates that may influence detection probability in the surveyed strip with MCDS and detection probability on the trackline with MRDS, including Beaufort sea state, cloud cover, glare intensity (level of visual obstruction due to sea surface glare), glare coverage (proportion of viewing area obstructed), and turbidity, along with interactions between distance and observer in the MRDS function (Supplemental File 1). All combinations of variables were considered for inclusion, and the best model was selected from the candidate models based on the lowest AIC. For a given trackline segment, search effort was expressed as the multiple of trackline length, estimated detection probability within the strip, and the truncation distance. Availability bias due to diving behavior was not addressed, although ongoing satellite tagging efforts are seeking to resolve this issue.

\section{North Atlantic Right Whale Consortium (NARWC) Surveys}

The North Atlantic Right Whale Consortium's sightings database serves as a repository for sightings of marine mammals, sea turtles, and large fishes, as well as for corresponding survey effort where available (North Atlantic Right Whale Consortium 2018). Survey platforms and protocols for recording manta sightings vary across the many contributors that submit data to the database. Therefore, most contributed datasets were used only for external validation of models, including sightings north of Cape Hatteras, vessel-based surveys, etc.). Surveys conducted by the New England Aquarium in a Skymaster airplane during November-March/April in 1989/90, 1990/91, and 1991/92 were the only surveys that reliably recorded sighting distances for mantas. These surveys were primarily conducted off Florida and Georgia during winter (November-April). Sightings distances for these surveys were reported in nautical mile intervals corresponding to wing strut markings on the survey platform and were converted to meters. For distance function fitting, sightings were restricted to on-effort sightings at altitudes of $\leq 366 \mathrm{~m}$ with Beaufort sea states of $\leq 4$. AlC was used to guide selection of the best-fitting detection function 
considering possible covariates of sea state, cloud cover, and glare using function ' $d s$ ' in the R 'Distance' package (Miller et al. 2019).

This detection function (Supplemental File) was then applied to estimate effective search area for oneffort surveys by FWRI from 2002 and 2010-2017, which were also conducted in a Skymaster and consistently recorded manta sightings but did not record detection distance. FWRI surveys were also primarily conducted off Florida and Georgia during winter. Because departures from the trackline for North Atlantic right whale sightings were not explicitly coded as such for the FWRI surveys, and it was unclear whether mantas would be recorded during this activity, off-track effort was eliminated by dropping waypoints that deviated from the previous heading by $>20$ degrees. Visual inspection of tracklines indicated this approach was effective at eliminating loops off the trackline. Sightings from all other surveys were retained for external validation of model fits, but not included in the distribution modeling input due to lack of clarity regarding whether mantas would have been explicitly recorded during all on-effort surveys and lack of data suitable for fitting a detection function.

\section{New York State Energy Research and Development Authority (NYSERDA) Surveys}

The New York State Energy Research and Development Authority (NYSERDA) contracted with Normandeau Associates Inc. (Normandeau) and teaming partner, APEM Ltd., to use high-resolution, largeformat aerial digital imagery to collect data on birds, marine mammals, sea turtles, cartilaginous fish, and other taxa encountered offshore within the New York Offshore Planning Area, an area spanning > 43,745 $\mathrm{km}^{2}$. Transect surveys of abutting imagery were conducted four times a year over three years between August 2016 and May 2019, with an area of $>3,000 \mathrm{~km}^{2}$ imaged on each survey representing $>7 \%$ coverage of the area. Each survey took between six and eight days to complete, depending on weather conditions and flight restrictions. Image resolution was $1.5 \mathrm{~cm}$ at the sea surface collected with downward-facing cameras from a flight altitude of $414.5 \mathrm{~m}$ and at a flight speed of $220 \mathrm{~km} / \mathrm{hr}$. Animal targets were extracted from imagery using a combination of detection software and manual review, with detected animals made available to taxonomists for species-level identification through Normandeau's ReMOTe data portal. All identifications underwent a quality-control review of $20 \%$ of identifications, Endangered species went through $100 \%$ review of identifications, and $10 \%$ of all imagery considered not to contain animal targets also underwent manual review. For the purposes of this analysis, all large rays were further reviewed to confirm species identification.

Effort was expressed as the swept area within the camera view, and detection probability was assumed to be $100 \%$ within the swept area for animals at or near the surface. To estimate size of detected manta rays, a measurement tool was created within the data portal utilizing known pixel resolution at the sea surface within every portion of each image. Measurements of animals using known pixel resolution at the sea surface were unable to compensate for the unknown depth of the animal in the water column and consequently an element of minor $(<5 \mathrm{~cm})$ but unquantifiable error is associated within estimations of disc width for observed manta rays. 


\section{Distribution Modeling}

Depth was assigned to transect segments from the National Oceanic and Atmospheric Administration (NOAA) National Centers for Environmental Information Coastal Relief Model (CRM), which provides 3 arc-second resolution bathymetry for most areas in the study domain. Data gaps were filled with 1 arcminute resolution bathymetry from the NOAA ETOP01 database using the R 'marmap' package (Pante and Simon-Bouhet 2013). Slope was derived from bathymetry using Spatial Analyst in ESRI ArcMap 10.7, with higher-resolution CRM-derived bathymetry and slope retained when available. Satellite observations of daily sea surface temperature (SST); daily k490 irradiance; and 8-day averaged chlorophyll-a (Chl-a), along with model-generated estimates of primary productivity; north-bound water velocity from HYCOM models; and predicted wave height from the Global Wave Model were assigned to daily transect segments from the ERDDAP server using the $\mathrm{R}$ 'rerddap'package (Chamberlain 2021). Frontal gradients of SST were computed following (Belkin and O'Reilly 2009) using the R 'grec'package (Lau-Medrano 2020). Daily standardized frontal gradients ('Front-Z') were computed by dividing frontal gradient raster values by the daily maximum within the raster domain. SST was evaluated because it was hypothesized that manta distributions would be limited by thermal tolerance. Primary productivity, k490 irradiance, Chl$a$, and Front-Z are all proxies for upwelling zones with high prey abundance, with differing levels of availability and model resolution in the time series. North-bound water velocity was hypothesized to capture potential use of the north-bound Gulf Stream and nearshore counter-current flow off the U.S. east coast. Predicted wave height was hypothesized to capture manta avoidance of rough water where surface zooplankton concentrations were unlikely and surface basking would be bioenergetically costly.

Sightings, effort, and environmental parameters for daily tracklines were summarized to a $10 \times 10-\mathrm{km}$ grid for all surveys. The $10 \times 10-\mathrm{km}$ model domain encompassed all surveys from all sources. Trackline segments were assigned to grid cells, sightings and effort were summed within each grid cell, depth and environmental characteristics were averaged within each cell, and the maximum observed value for bathymetric slope on the trackline segment was retained. Generalized additive models (GAMs) were fit to all possible permutations of bathymetry and environmental parameters using the ' $m g c v^{\prime}$ 'package in $\mathrm{R}$ (Wood 2011), with log-transformed effort derived from the survey-specific detection functions as an offset. GAMs were fit with a binomial distribution using a logit link function, such that the resultant models describe the probability of species presence, also termed "habitat suitability" (Brodie et al. 2018) or "habitat preference" (Hazen et al. 2017). To minimize effects of collinearity, correlated predictor variables were not included in the same model. For example, Chl-a, primary productivity, and k490 were highly correlated and were tested separately but never included in the same model. Because Front-Z was derived from SST rasters, an interaction term for SST and Front-Z was also tested. Models were fit using a binomial distribution with tensor splines limited to 3 knots (Wood 2011). Preliminary model-fitting showed a tendency for overprediction at the extremes (especially peak positive values) when extrapolating predictions to other months/years. Constraining to 3 knots eliminated this issue while preserving the functional relationships with environmental covariates. The best-fitting model was selected by lowest AIC and compared to three competing GAM configurations tiered off the best-fitting 
GAM by excluding non-significant terms in the model summary. For each survey, the final model was selected by comparing residual deviance explained and predictive power as evaluated through 10 -fold internal cross-validation and external validation using independent sources. Cross-validation was conducted using the 'pROC' package in R (Xavier et al. 2011), generating estimates for area under the curve (AUC) and associated false positive and false negative rates for a model fit to $90 \%$ of the available data compared to sighting locations from the remaining $10 \%$ of the data. External validation was similarly accomplished using pROC to evaluate AUC for the full GAM model compared to sighting records from independent sources, including off-effort sightings from the survey under evaluation. For external validation through AUC, sighting effort was unknown, and assumed equal to mean sighting effort from distance-sampling surveys. As such, external validation outcomes were less reliable for evaluating quality of model fit but useful for relative comparison between models. An additional external validation metric was developed to gauge consistency between SDM predictions and the locations of independent sightings of manta rays. We divided SDM predictions for point-specific independent sightings by domainwide daily median Z-score transformed SDM predictions across valid depths, then centered these transformed scores to zero by subtracting one. The greater the proportion of retained Z-scores above zero, the higher the consistency between SDM predictions and independent observations (Farmer et al. 2017, Heyman et al. 2019).

We fit models to each survey independently following the approaches above. Due to the limited spatiotemporal coverage of distance-sampling data for the NARWC and NYSERDA data, those SDM results were not reported independently, but were used to generate ensemble models following two approaches. The first ('weighted ensemble') was a weighted mean prediction across the best models fit to the three independent surveys (i.e. SEFSC, NARWC, and NYSERDA). Model predictions for each 10-km cell were expressed as a weighted mean across the three surveys, with the complement of the standard error (i.e., 1-SE) of the model prediction from each survey used as the weighting term, to place more emphasis on the model prediction with the least uncertainty at that given location. The second ('combined surveys') was developed by fitting a GAM using the iterative fitting process described above to an appended data series of all three surveys combined, with survey-specific sighting effort expressed in the same units of swept area $\left(\mathrm{m}^{2}\right)$.

Annual trends in predicted manta distributions were evaluated by fitting previously described distribution models for SEFSC, NARWC, and combined data to monthly average environmental conditions from January 2003 to December 2019. The monthly weighted mean latitudinal centroid of predicted manta distribution was computed for each model. Seasonal auto-regressive integrated moving average (SARIMA) time-series models with annual and monthly differencing terms were fit using $\mathrm{R}$ package "astsa" (Stoffer 2020, Shumway \& Stoffer 2017). As no annual terms were included in the model, our SDM assumed stationary overall probability of occurrence across years; thus, any interannual differences in mean probability of occurrence would be driven only by differences in the dynamic terms in the model (e.g., SST, frontal gradients, Chl-a) rather than changes in population abundance. 


\section{Results}

\section{Sightings}

Over 5000 purported manta sightings were identified in the EUS from 1925 to 2020 (Table 1, Fig. 1).

Dedicated aerial surveys for manta rays off northeastern Florida funded by the Georgia Aquarium had the most sightings, followed by the multi-contributor NARWC data which covered much of the U.S. east coast. In the Gulf of Mexico, the highest concentration of sightings was in nearshore waters off Louisiana. On the U.S. east coast, the highest concentration of sightings was in nearshore to shelf-edge waters off Florida and Georgia and nearshore and shelf-edge waters from Cape Hatteras north to New York. Anecdotal manta sightings were also recorded in waters around Puerto Rico and the U.S. Virgin Islands. In the U.S. Virgin Islands, small manta rays were sighted in shallow coastal bays such as Cane's Bay, Maho Bay, and Francis Bay. In Puerto Rico, the majority of manta sightings were reported from the area surrounding Culebra, Vieques, and Mona Islands. The bulk of manta sightings were recorded between 26 and $30^{\circ} \mathrm{N}$, with the highest number of sightings from March through May. The vast majority (82\%) of sightings north of $35^{\circ} \mathrm{N}$ were recorded from June to September (Fig. 2). 
Table 1

Geographic and temporal range for data sources for giant manta ray ( $M$. birostris) sightings, with number (N) sighted.

\begin{tabular}{|c|c|c|c|c|c|}
\hline Source & Years & $\mathbf{N}$ & $\begin{array}{l}\text { Latitude } \\
\left({ }^{\circ} \mathrm{N}\right)\end{array}$ & Area & Description \\
\hline Anecdotal & $\begin{array}{l}1999- \\
2020\end{array}$ & 239 & $17-34$ & Global & $\begin{array}{l}\text { Verified reports to the authors and } \\
\text { manta.ray@noaa.gov, social media, } \\
\text { press reports. }\end{array}$ \\
\hline FAU & $\begin{array}{l}2014- \\
2019\end{array}$ & 99 & $25-27$ & $\begin{array}{l}\text { Miami Beach } \\
\text { to Jupiter } \\
\text { Inlet, Florida, } \\
\text { USA }\end{array}$ & $\begin{array}{l}\text { Florida Atlantic University Kajiura Lab } \\
\text { aerial elasmobranch surveys }\end{array}$ \\
\hline FGBNMS & $\begin{array}{l}1990- \\
2017\end{array}$ & 144 & $27-29$ & $\begin{array}{l}\text { Offshore } \\
\text { Texas, USA }\end{array}$ & $\begin{array}{l}\text { Sightings recorded in dive logs by } \\
\text { Flower Garden Banks National } \\
\text { Marine Sanctuary staff }\end{array}$ \\
\hline FMP & $\begin{array}{l}2016- \\
2020\end{array}$ & 142 & $26-28$ & $\begin{array}{l}\text { Hollywood to } \\
\text { Port Salerno, } \\
\text { Florida, USA }\end{array}$ & $\begin{array}{l}\text { Boat-based and aerial surveys by } \\
\text { trained Florida Manta Project staff, } \\
\text { with in-water estimates of size }\end{array}$ \\
\hline FSU & 2019 & 1 & $29-30$ & $\begin{array}{l}\text { Florida } \\
\text { Panhandle, } \\
\text { USA }\end{array}$ & $\begin{array}{l}\text { Florida State University Grubbs Lab } \\
\text { elasmobranch gillnet survey }\end{array}$ \\
\hline FWRI & $\begin{array}{l}2018- \\
2020\end{array}$ & 122 & $27-30$ & Florida, USA & $\begin{array}{l}\text { Florida Fish and Wildlife Research } \\
\text { Institute aerial surveys from OBIS } \\
\text { (2018-2019) and J. Jakush (pers. } \\
\text { comm. to C. Horn, 2020). }\end{array}$ \\
\hline GAl & $\begin{array}{l}2010- \\
2017\end{array}$ & 1536 & $28-30$ & $\begin{array}{l}\text { St. Augustine } \\
\text { Inlet to Cape } \\
\text { Canaveral, } \\
\text { Florida, USA }\end{array}$ & Georgia Aquarium aerial surveys \\
\hline IOBIS & $\begin{array}{l}1925- \\
2016\end{array}$ & 1361 & $\begin{array}{l}36^{\circ} \mathrm{S}- \\
44^{\circ} \mathrm{N}\end{array}$ & Global & $\begin{array}{l}\text { Ocean Biodiversity Information } \\
\text { System open-access data }\end{array}$ \\
\hline NARWC & $\begin{array}{l}1979- \\
2017\end{array}$ & 1240 & $26-40$ & $\begin{array}{l}\text { Florida to } \\
\text { Maine, USA }\end{array}$ & $\begin{array}{l}\text { Ship-based and aerial surveys by } \\
\text { North Atlantic Right Whale } \\
\text { Consortium observers }\end{array}$ \\
\hline $\begin{array}{l}\text { NEFSC- } \\
\text { NEOP }\end{array}$ & $\begin{array}{l}1993- \\
2014\end{array}$ & 8 & $35-40$ & $\begin{array}{l}\text { North } \\
\text { Carolina to } \\
\text { Maine, USA }\end{array}$ & $\begin{array}{l}\text { Northeast Fisheries Science Center } \\
\text { Northeast Observer Program observer } \\
\text { records in trawl gear }\end{array}$ \\
\hline NYSERDA & $\begin{array}{l}2016- \\
2017\end{array}$ & 6 & $39-41$ & $\begin{array}{l}\text { New York: } \\
\text { Long Island } \\
\text { to the lower } \\
\text { slope roughly } \\
\text { between } \\
\text { South } \\
\text { Wilmington } \\
\text { Canyon and } \\
\text { Block Canyon }\end{array}$ & $\begin{array}{l}\text { APEM and Normandeau Associates } \\
\text { Aerial Digital Baseline Survey of } \\
\text { Marine Wildlife in Support of } \\
\text { Offshore Wind Energy for New York } \\
\text { State Energy Research and } \\
\text { Development Authority (NYSERDA) } \\
\text { and U.S. Bureau of Ocean Energy } \\
\text { Management. }\end{array}$ \\
\hline
\end{tabular}




\begin{tabular}{|c|c|c|c|c|c|}
\hline Source & Years & $\mathbf{N}$ & $\begin{array}{l}\text { Latitude } \\
\left({ }^{\circ} \mathrm{N}\right)\end{array}$ & Area & Description \\
\hline Publication & $\begin{array}{l}1993- \\
1994\end{array}$ & 3 & $27-29$ & $\begin{array}{l}\text { Indian River } \\
\text { Lagoon, } \\
\text { Florida, USA }\end{array}$ & Adams \& Amesbury (1998) \\
\hline $\begin{array}{l}\text { SEFSC- } \\
\text { AMAPPS }\end{array}$ & $\begin{array}{l}2010- \\
2019\end{array}$ & 367 & $27-40$ & $\begin{array}{l}\text { Florida to } \\
\text { New Jersey, } \\
\text { USA }\end{array}$ & $\begin{array}{l}\text { Southeast Fisheries Science Center } \\
\text { Atlantic Marine Assessment Program } \\
\text { for Protected Species aerial surveys }\end{array}$ \\
\hline $\begin{array}{l}\text { SEFSC- } \\
\text { GOMMAPPS }\end{array}$ & $\begin{array}{l}2017- \\
2018\end{array}$ & 109 & $25-31$ & $\begin{array}{l}\text { Gulf of } \\
\text { Mexico (U.S. } \\
\text { waters) }\end{array}$ & $\begin{array}{l}\text { Southeast Fisheries Science Center } \\
\text { Gulf of Mexico Marine Assessment } \\
\text { Program for Protected Species aerial } \\
\text { surveys }\end{array}$ \\
\hline $\begin{array}{l}\text { SEFSC- } \\
\text { GOMNRDA }\end{array}$ & $\begin{array}{l}2011- \\
2012\end{array}$ & 119 & $25-31$ & $\begin{array}{l}\text { Gulf of } \\
\text { Mexico (U.S. } \\
\text { waters) }\end{array}$ & $\begin{array}{l}\text { Southeast Fisheries Science Center } \\
\text { Gulf of Mexico Natural Resource } \\
\text { Damage Assessment program aerial } \\
\text { surveys }\end{array}$ \\
\hline $\begin{array}{l}\text { SEFSC-MS } \\
\text { Lab Survey }\end{array}$ & $\begin{array}{l}1982- \\
2015\end{array}$ & 5 & $28-30$ & $\begin{array}{l}\text { Gulf of } \\
\text { Mexico (U.S. } \\
\text { waters) }\end{array}$ & $\begin{array}{l}\text { Southeast Fisheries Science Center } \\
\text { Mississippi Lab pelagic longline } \\
\text { survey }\end{array}$ \\
\hline SEFSC-RVC & $\begin{array}{l}2000- \\
2013\end{array}$ & 6 & $24-27$ & $\begin{array}{l}\text { Dry Tortugas } \\
\text { and Florida } \\
\text { Keys, USA }\end{array}$ & $\begin{array}{l}\text { Southeast Fisheries Science Center } \\
\text { Reef Visual Census SCUBA-based } \\
\text { survey }\end{array}$ \\
\hline
\end{tabular}

\section{SEFSC Surveys}

The combined SEFSC surveys covered U.S. waters in the Gulf of Mexico and the U.S. east coast, with comprehensive spatiotemporal coverage of most months other than March and September (Fig. 2A-B). The most sightings and largest groups were reported in the Gulf of Mexico near the mouth of the Mississippi River, the east coast of Florida, and off Cape Hatteras, North Carolina (Fig. 2A). Sightings north of $35^{\circ} \mathrm{N}$ were reported throughout the year, with the majority in July-August (Fig. 2B). In the markrecapture distance-sampling framework, the selected MCDS model included cloud cover, and the selected MRDS function included glare and an interaction between observer and distance (Supplemental File). Average detection probability within the $300 \mathrm{~m}$ swept area was $39.4 \%$ (CV $=11.9 \%)$.

\section{NARWC Surveys}

The NARWC surveys covered the U.S. east coast, with temporal coverage of all months over the span of the survey; however, only a limited subset, primarily off Florida and Georgia in the winter, contained sufficient distance-sampling information to be used in the SDM (Fig. 2C-D). The most sightings and the largest groups were sighted off Florida and Georgia (Fig. 2C). Sightings were reported in all months except May and October (Fig. 2D). The vast majority of sightings north of $35^{\circ} \mathrm{N}$ were reported during June-September (Fig. 2D). The selected detection function was a half-normal key function of sea state (Supplemental File). Average detection probability within the $348 \mathrm{~m}$ swept area was $55.5 \%(\mathrm{CV}=48.6 \%$ ). 
The NYSERDA surveys covered the nearshore to offshore marine environments of New York, with temporal coverage during the spring/summer of 2016-2019 and fall/winter of 2016-2018 (Fig. 2E-F). Of the 21,539 rays identified in the surveys, 504 were initially identified as manta rays; however, review of digital photo archives by a trained observer determined only 7 were actually manta rays. The majority of misidentified rays were M. mobular or M. tarapacana. All manta sightings and $>99 \%$ of all ray (all species) sightings were in summer. Despite comprehensive coast to shelf survey coverage, manta sightings were exclusively in August on the continental shelf edge.

\section{Distribution Modeling}

SDMs generated from combined SEFSC surveys explained $4-5 \%$ of residual deviance (Table 2). AUC for internal and external validation were comparable and indicated "acceptable" model fits (Hosmer and Lemeshow 2013; Table 2). Sighting probability was highest at SSTs from 17 to $32^{\circ} \mathrm{C}$, with peak probability around $23^{\circ} \mathrm{C}$. Sighting probability was highest close to shore at strong thermal fronts. The final SEFSC survey SDM predicted fairly high probability of occurrence $(>25 \%)$ during most of the year south of Cape Hatteras, North Carolina (Fig. 3). Peak probability of occurrence in the Gulf of Mexico and south of Cape Hatteras was predicted during cooler months (November-April), with peak probability of occurrence north of Cape Hatteras during warmer months (May-October).

The 'weighted ensemble' of SDMs generated from the SEFSC, NARWC, and NYSERDA surveys had an "acceptable" predictive fit (Table 2; Hosmer and Lemeshow 2013). The weighted ensemble SDM predicted a relatively uniform probability of occurrence in nearshore environments (Fig. 4). 
Table 2

Model fit summaries for different survey datasets with Akaike Information Criterion (AIC), residual deviance explained (DevExpl), and Area under the Curve (AUC) from ten-fold internal (int) and external (ext) cross-validation from independent samples. Selected model in bold for each survey. 'Combined Surveys' denotes models fit to data from the SEFSC, NARWC, and NYSERDA surveys.

\begin{tabular}{|c|c|c|c|c|c|}
\hline \multirow[t]{2}{*}{ Survey } & \multirow[t]{2}{*}{ Model } & \multirow[t]{2}{*}{ AlC } & \multirow{2}{*}{$\begin{array}{l}\text { Dev } \\
\text { Expl }\end{array}$} & \multirow{2}{*}{$\begin{array}{l}\text { AUC } \\
\text { (int) }\end{array}$} & \multirow{2}{*}{$\begin{array}{l}\text { AUC } \\
\text { (ext) }\end{array}$} \\
\hline & & & & & \\
\hline SEFSC & $\begin{array}{l}\text { offset(log(striparea)) + Front_ZxSST + Front_Z } \\
+ \text { SST + pp + Depth_m + Slope_deg + } \\
\text { DfromShore }\end{array}$ & 1808 & $5.4 \%$ & $74.9 \%$ & $74.8 \%$ \\
\hline SEFSC & $\begin{array}{l}\text { offset(log(striparea) })+ \text { Front_Z + SST + } \\
\text { DfromShore + pp }\end{array}$ & 1809 & $5.2 \%$ & $74.6 \%$ & $74.6 \%$ \\
\hline SEFSC & $\begin{array}{l}\text { offset(log(striparea)) + Front_Z + SST + } \\
\text { Depth_m + ChIA }\end{array}$ & 1890 & $4.4 \%$ & $73.3 \%$ & $73.3 \%$ \\
\hline SEFSC & offset $(\log ($ striparea $))+$ Front_Z + SST + ChIA & 1895 & $4.1 \%$ & $72.6 \%$ & $72.6 \%$ \\
\hline SEFSC & $\begin{array}{l}\text { offset(log(striparea)) + Front_Z + SST + } \\
\text { DfromShore }\end{array}$ & 1997 & $5.3 \%$ & $75.0 \%$ & $75.0 \%$ \\
\hline $\begin{array}{l}\text { Combined } \\
\text { Surveys }\end{array}$ & $\begin{array}{l}\text { offset(log(striparea) })+ \text { Front_Z×SST + SST + } \\
\text { pp + Depth_m + Slope_deg }\end{array}$ & 3328 & $18.5 \%$ & $84.8 \%$ & $84.8 \%$ \\
\hline $\begin{array}{l}\text { Combined } \\
\text { Surveys }\end{array}$ & $\begin{array}{l}\text { offset(log(striparea)) + Front_Z×SST + SST + } \\
\text { Depth_m + Slope_deg }\end{array}$ & 3563 & $19.0 \%$ & $84.8 \%$ & $84.8 \%$ \\
\hline $\begin{array}{l}\text { Combined } \\
\text { Surveys }\end{array}$ & $\begin{array}{l}\text { offset(log(striparea)) + Front_Z×SST + SST + } \\
\text { Depth_m + Slope_deg + ChIA }\end{array}$ & 3368 & $19.3 \%$ & $85.2 \%$ & $85.2 \%$ \\
\hline $\begin{array}{l}\text { Combined } \\
\text { Surveys }\end{array}$ & $\begin{array}{l}\text { offset(log(striparea)) + SST + Depth_m + } \\
\text { Slope_deg + ChIA }\end{array}$ & 3395 & $18.5 \%$ & $85.0 \%$ & $85.0 \%$ \\
\hline $\begin{array}{l}\text { SEFSC, } \\
\text { NARWC, \& } \\
\text { NYSERDA }\end{array}$ & Weighted Ensemble SDM & 1163 & $18.7 \%$ & $84.7 \%$ & $84.7 \%$ \\
\hline
\end{tabular}

The 'combined surveys' SDM that integrated sightings and effort from SEFSC, NARWC, and NYSERDA surveys predicted higher probabilities of observation with warm SST, moderate Front-Z, nearshore and shelf-edge depths, moderate bathymetric slopes, and increasing Chl-a concentrations (Fig.5). AUC for internal and external validation were comparable and indicated "excellent" model fits (Hosmer and Lemeshow 2013; Table2). The combined surveys SDM explained 19\% of residual deviance (Table2).

The combined surveys SDM predicted highest probabilities of detection at offshore sloped habitats (e.g., seamounts) and in the nearshore environment off Louisiana at the Mississippi River delta between April to June and again in October (Fig. 6). Probability of occurrence increased at moderate frontal gradients with SSTs between 20 and $30^{\circ} \mathrm{C}$ in both nearshore and shelf-edge environments with moderate slopes and high concentrations of Chl-a (Figs. 5-6). 
External validation of the SEFSC and combined survey models was challenged by a lack of necessary environmental data for many independent manta ray observations. Some observations were from periods before satellite data were collected; others were too close to shore to generate frontal gradients. However, where models could be successfully fit, external validation suggested high predictive utility to independent observations, especially for the combined survey model (Fig. 7). The median Z-score standardized probabilities of observation were significantly greater than 0 for both surveys [SEFSC: $t(14657)=241.39, p<0.0001, \overline{\mathrm{x}}(95 \% \mathrm{Cl})=0.592(0.588-0.597)$, Combined: $t(4036)=59.86, p<0.0001$, $\overline{\mathrm{x}}(95 \% \mathrm{Cl})=0.873(0.844-0.902)]$, confirming that SDM predictions were highly consistent with independent observations of manta rays (Fig. 7).

All SDMs predicted similar spatio-temporal distribution trends (Figs. 3, 4, 6), with higher probabilities of detection on the inside edge of the Gulf Stream from January to April, and peak nearshore distribution off Northeast Florida and Georgia during April. The predicted distribution extends northward during May and then the peak relocates north of Cape Hatteras from June to October. The peak then collapses back to nearshore Georgia and Florida's east coast, and the Gulf of Mexico from November to December. In the Gulf of Mexico, the peak was concentrated near the Mississippi River delta during the spring and fall, but more dispersed and farther from shore during the rest of the year. This pattern corresponds to seasonal fluctuations in productivity, as inferred from Chl-a, and SST (Supplemental File).

Plots were generated from January 2003 to December 2019 for the SEFSC, NARWC, and combined surveys SDMs (Supplemental File). SARIMA models for all three SDMs indicated a significant monthly trend in weighted mean central latitudinal distribution (SEFSC: seasonal model average sma $1=-0.98$, $t(189)=-2.63, p=0.0093$; NARWC: $s m a 1=-0.96, t(189)=-4.94, p<0.0001$; Combined Surveys: $s m a 1=-1.00$, $t(189)=-10.3241, p<0.0001)$. For both the SEFSC and NARWC models, SARIMA models indicated a significant northerly trend in weighted mean central latitudinal distribution over the 2003-2019 timeseries (SEFSC: auto-regressive $\operatorname{ar} 1=0.42, t(189)=6.51, p<0.0001$; NARWC: $\operatorname{ar} 1=0.39, t(189)=5.89, p<$ 0.0001). Forward-projection of the SARIMA model predicted a continued northern shift in the overall distribution of manta rays from 2020 through 2024 (Fig. 8).

Size estimates for manta rays were limited, but suggest that smaller animals, likely juveniles, were more common in the warmer waters of the Gulf of Mexico, Florida, and Georgia (Figure 9), whereas larger individuals were observed farther north. Anecdotal observations, supported by photo and/or video, of small $(1.7 \mathrm{~m})$ individuals from shallow bays in the U.S. Caribbean were also reported.

\section{Discussion}

A major conservation priority for giant manta ray recovery is to improve our understanding of movement and seasonal distribution patterns to inform future management measures for minimizing impacts to the species during key life history functions (NOAA 2020). Within its global range, giant manta rays inhabit tropical, subtropical, and temperate bodies of water and are commonly found offshore, in oceanic waters, and near productive coastlines (Marshall et al. 2009; Kashiwagi et al. 2011; Pate \& Marshall 2020). Our 
analysis of decades of manta ray sightings across several different aerial survey platforms in the EUS indicated manta rays were most commonly detected at frontal boundaries in productive nearshore and shelf-edge upwelling zones within a thermal optima of approximately $15-30^{\circ} \mathrm{C}$ (Fig. 5). These findings are consistent with ecologically-driven expectations that manta rays would be more common near areas of potentially high prey densities (upwelling zones) within thermally optimal conditions. For the Gulf of Mexico, peak occurrence and observations were clustered off the Mississippi River delta, an area of known high concentrations of large zooplankton (Figs. 3 and 7 in Shropshire et al. 2020). Shropshire et al. (2020)'s predictive maps also illustrate the importance of nearshore habitats as a potential food source for manta rays. Similarly, zooplankton biomass estimates by Strömberg et al. (2009) suggest high concentrations of potential manta ray prey in the Mississippi River plume, Florida coastal waters, the upwelling zone near Cape Hatteras, North Carolina, and the northeastern United States shelf-edge areas covered by the NYSERDA surveys.

It is noteworthy that $>99 \%$ of all rays (all species) observed by the NYSERDA surveys were observed in the spring/summer, despite nearly equal levels of survey effort in the fall/winter. Environmental temperature directly dictates body temperature for most elasmobranchs (Huey and Kingsolver 1989; Deutsch et al. 2008; Schulte et al. 2011). Many physiological rates scale with temperature according to a thermal performance curve, with performance gradually increasing up to an organism's optimum temperature, and then quickly declining as temperatures approach lethal levels (Huey and Stevenson 1979; Angilletta et al. 2002; Angilletta 2006, Lear et al. 2019). Manta and devil rays routinely exhibit basking behaviors presumably to elevate body temperatures after making excursions into deeper, colder habitats (e.g. Thorrold et al. 2014). Cold winter air and sea surface temperatures in the western North Atlantic Ocean likely create a physiological barrier to manta (and other) rays that restricts the northern boundary of their distribution.

Juvenile elasmobranchs appear to have wide performance curves characteristic of thermal generalists, which may allow them to survive and succeed in shallow coastal areas subject to more rapid temperature fluctuation and higher maximum temperatures (Gilchrist 1995; Kingsolver 2009; Lear et al. 2019). By contrast, adults may have steeper, narrower thermal performance curves to achieve high levels of performance once they gain the ability to migrate long distances and select habitats with preferred thermal characteristics (Lear et al. 2019). Globally, the species has been observed in estuarine waters near oceanic inlets (Adams and Amesbury 1998; Milessi and Oddone 2003; Medeiros et al. 2015). Potential manta nursery habitats have been identified at FGBNMS in the Gulf of Mexico and in the nearshore waters of southeastern Florida (Stewart et al. 2018; Pate \& Marshall 2020). The use of warmer waters at smaller sizes is consistent with bioenergetic theory, as optimal temperature for growth is higher for smaller fish (Morita et al. 2010). Unlike other areas within the survey domain, southeastern Florida maintains water temperatures within the predicted optimum year-round, minimizing requirements for movement, which may explain repeated resightings across multiple years for specific juveniles (Pate \& Marshall 2020). Similarly, FGBNMS mean temperatures remain in the $20-30^{\circ} \mathrm{C}$ range year-round (see Fig. 8.1 in Johnston et al. 2018). 
In this study, SST was the strongest single predictor of manta distribution, with a strong thermal preference apparent between 17 and $32^{\circ} \mathrm{C}$, with a peak around $23^{\circ} \mathrm{C}$. Temperature preference appears to vary by region, with manta rays off the U.S. east coast commonly found in waters from 19 to $22^{\circ} \mathrm{C}$ and those off the Yucatan peninsula and Indonesia between 25 and $30^{\circ} \mathrm{C}$ (Duffy and Abbott 2003; Marshall et al. 2009; Freedman \& Roy 2012; Graham et al. 2012; Hacohen-Domené et al. 2017). Garzon et al. (2020) found Chl-a, bathymetric slope, and SST were important drivers of manta distribution in the Western Central Atlantic (WCA); however, SST was the least important driver in their model, possibly due to the lower variability in SST in the WCA relative to the U.S. east coast.

The combined surveys model indicated highest probability of occurrence at moderately-sloped nearshore and shelf-edge habitats with moderate SST fronts and high concentrations of Chl-a; all proxies for high primary production and associated manta prey availability (Fig. 5). Due to the lack of spatially comprehensive zooplankton and micronekton sampling data, we were unable to explicitly test associations between manta rays and prey availability. However, strong associations were observed across data sources between manta ray sightings and proxies for productive upwelling zones. Within thermally-optimal bounds, models predicted higher concentrations of manta rays from the coast to the shelf south of Cape Hatteras, approximately corresponding with the inside edge of the Gulf Stream current. Offshore, the inside edge of warmer Gulf Stream waters passing the continental shelf provides a consistent source of upwelling and productivity (Blanton et al. 1981). Similarly, nearshore tidal fronts provide mixing and nutrient concentrations to support high concentrations of potential prey items (Savidge 1976; Pingree et al. 1978; Tett 1981). The offshore, northbound flow of the Gulf Stream is offset by the nearshore, southbound counter-current flow (Bumpus \& Wehe 1949), and may provide a bioenergetically favorable 'conveyor belt' for filter-feeding manta rays to efficiently forage while remaining within thermally-optimal conditions. Satellite-tagging studies are needed to evaluate individual movement patterns and quantify population connectivity.

We observed a dome-shaped relationship with temperature and significant seasonal and interannual trends in the centroid of manta distributions, suggesting that the population may be impacted by climate change similar to swordfish (Brodie et al. 2021) and North Atlantic right whales (Record et al. 2019). If relatively prey-rich northern waters continue to warm, the overall distribution may continue to shift northwards (Figs. 4, 8, Supplemental Video). Warming SST leads to more stable water columns, enhancing stratification and requiring more energy to mix deep, nutrient-rich water into surface layers (review in Richardson 2008). Nutrient limitation in phytoplankton growth in the ocean is negatively related to temperature globally (Kamykowski \& Zentara 2005). In response to global warming, poleward shifts in zooplankton distribution coupled with changes in abundance and community structure are anticipated (Richardson 2008). Changes in climate and oceanographic conditions, such as acidification, are also known to affect zooplankton structure (size, composition, diversity), phenology, and distribution (Guinder and Molinero 2013). The major impact of climate change on mobulids is likely to be the projected decline in zooplankton in tropical waters (Stewart et al. 2018). Future research should identify manta prey in the EUS, determine the environmental drivers of their prey distribution, and evaluate how those distributions are likely to shift under climate change scenarios.

Page 18/39 
Retrospective analyses of NYSERDA and discussions with aerial observers (Table 1) suggested that $M$. mobular and $M$. tarapacana were frequently misidentified as giant manta rays, especially north of Cape Hatteras, North Carolina. We addressed this uncertainty by only including photographically-verified sightings north of Cape Hatteras in our modeling efforts. Interviews with observers and reviews of $100 \mathrm{~s}$ of photos suggested extremely low misidentification rates south of Cape Hatteras; however, photos were not available for all sightings and observer aerial survey guides were not developed until after the listing. As such, our SDMs may to some extent represent a shared habitat utilization of mobulid species, heavily weighted towards manta rays. The Normandeau Associates/APEM digital photo archives for NYSERDA and BOEM data allowed us to compare sightings locations for confirmed species identifications of large mobulids, including manta rays, and revealed substantial overlap in species habitat utilization along the U.S. East Coast's continental shelf from South Carolina to New York (see Supplemental File). Due to a lack of distinguishing dorsal features, we were unable to account for the putative third species or subspecies of M. birostris (M. sp. cf. birostris sensu Marshall et al. 2009) resident in the Gulf of Mexico (Clark 2002; Hinojosa-Alvarez et al. 2016; Hosegood et al. 2020) and possibly southeastern Florida (Pate \& Marshall 2020). Given possible hybridization with M. birostris (Hosegood et al. 2020), and apparent overlap in distribution, genetic, and morphological similarities, this possible misidentification may have limited impact upon modeled manta distributions. Without genetic testing, species identification cannot be completely validated (Hinojosa-Alvarez et al. 2016; Kashiwagi et al. 2017; Hosegood et al. 2020). The distribution of M. birostris and M. sp. cf. birostris sensu (Marshall et al. 2009) may be of similar management interest due to the inability to readily distinguish between the two. If thermal tolerances vary between the two, our SDMs might over- or under-predict giant manta ray distributions in some regions. Similarly, our model does not account for any differences in depth utilization (e.g., availability bias); if manta rays spend proportionally more time in waters below the visual observation depth at particular locations, the model would underpredict their utilization of those areas.

In the United States, NOAA's National Marine Fisheries Service (NMFS) is charged with promoting the recovery of giant manta rays. Under Sect. 7 of the ESA, agencies must consult with NMFS to ensure their proposed actions do not jeopardize the survival of listed species. Understanding the distribution, abundance, migration patterns, and site fidelity of manta rays is essential for accurately estimating the impact of proposed activities. Anthropogenic impacts to individuals can be estimated as the product of: (i) the probability of an activity occurring in an area; (ii) the probability of an individual being in an activity area, expressed as a distribution model; (iii) the duration of exposure of the individual to the activity; and (iv) the probability of the activity impacting the individual, often expressed as a dose-response curve. Our SDMs will help managers determine when an effect of a proposed action on giant manta rays is likely based on the probability of an action taking place when giant manta rays are anticipated in the area. Even when duration of exposure and probability of adverse effects are unknown, relative risk assessments can be used to identify preferred alternatives, following Farmer et al. (2016). To more accurately determine anticipated take of giant manta rays from proposed actions, further information is needed on movements, site fidelity, depth utilization, and responses to anthropogenic stressors. 
The most significant threat to the recovery of giant manta rays across their range is intentional harvest and bycatch in fisheries (Miller and Klimovich 2017). Manta rays are targeted or caught as bycatch with virtually every fishing gear type, including small-scale fisheries characterized by the use of driftnets, gillnets, harpoons, gaffs, traps, trawls, and longlines; and large-scale fisheries using driftnets, trawls and purse seines (Croll et al. 2016). Our SDMs will help managers identify areas of spatial and temporal overlap between giant manta rays and commercial fisheries, which could be used to reduce bycatch rates in the EUS. Similarly, a better understanding of the spatiotemporal distribution of the species may help improve precision of bycatch estimates by controlling for relative availability of the species to the gear on any given set and allocating observer coverage to areas of higher bycatch concern. For example, preliminary analysis of 2019-2020 data estimated mean EUS shrimp trawl take of manta rays of nearly 1700 individuals/yr (Carlson 2020); however, uncertainty was very high given the short time series and limited data. Although observer coverage on shrimp trawls in the EUS is around 1\%, the relative observer coverage on shrimp trawls with trawl effort spatially weighted by manta probability of occurrence was less than $0.09 \%$ (Farmer NA, unpublished data).

A major NMFS recovery priority for giant manta rays is to investigate the impact of other threats to the species (e.g., foul-hooking, vessel strikes, entanglement, climate change, pollution, tourism) through research, monitoring, modeling, and management (NOAA 2020). Pate \& Marshall (2020) and our SDMs suggest that manta rays are frequently associated with nearshore habitats; as such, they are at elevated risk for exposure to a variety of contaminants and pollutants, including brevetoxins, heavy metals, polychlorinated biphenyls, and plastics (Essumang 2010; Ooi et al. 2015). Many of these toxins can bioaccumulate over decades in long-lived filter feeders, leading to a disruption of biological processes (e.g., endocrine disruption), and potentially altering reproductive fitness (Germanov et al. 2019). Coastal and lagoon habitats are especially sensitive to habitat degradation, pollution, and sedimentation (McCauley et al. 2012, 2014).

There is a strong management interest in understanding the inshore extent of manta movements in bays and tidal inlets. SDM predictions suggest seasonal trends with high probability of occurrence in large bays (e.g., Tampa Bay, Chesapeake Bay); however, reported sightings in bays are extremely limited. It is unclear if this is due to reduced water clarity, rarity of use, or very low levels of survey effort. Both Medeiros et al. (2015) and Bucair et al. (2021) report manta ray utilization of bays and inlets in Brazil, and we verified several anecdotal reports of use of shallow tropical bays in the U.S. Caribbean. Future efforts will seek to evaluate EUS nearshore sightings relative to currents, tidal phase, and salinity. Manta rays are frequently reported in nearshore environments of southeastern Florida (Pate \& Marshall 2020) and somewhat regularly in the U.S. Caribbean. Georgia Aquarium and partners recorded high numbers of manta rays between St. Augustine Inlet, Matanzas Inlet, and Jacksonville, Florida during dedicated aerial surveys in 2010-2017 (Table 1); however, the timing and frequency of these observations was variable both seasonally and interannually, with the peak only lasting a few weeks. SDMs capture these trends (Supplemental Video 1), predicting a spring and fall peak in the survey area with the spring peak varying between March and June. 
Florida, and southeastern Florida, specifically, has the highest number of registered recreational vessels and licensed recreational anglers in the U.S., and likely the world (USCG 2019). Manta rays are exposed to exceptionally high levels of vessel traffic as well as hook-and-line fishing gear from boats and piers. Manta rays are often observed foraging on tidal outflows at major inlets in the Palm Beach County area, leading to frequent overpasses by vessels moving at high speeds (Pate \& Marshall 2020). Casting in the vicinity of large mantas is a major component of the recreational cobia fishery along most of the Florida coast (Roberts 2020, Pate J, unpublished data, Farmer NA, unpublished data). Pate and Marshall (2020) documented fishing line entanglement on $27 \%$ of individuals in Palm Beach County, Florida, along with vessel strike injury and rapid wound healing. Pate et al. (2021) identified a need for outreach in the Palm Beach County area, focused on preventing recreational fishery interactions with manta rays, encouraging use of environmentally-friendly tackle, and fostering engagement with anglers as citizen scientists. Our SDMs will allow managers to more effectively time and coordinate management strategies, including targeted outreach efforts and developing spatiotemporal 'windows' for action agencies to reduce the risk of manta interactions.

A major priority for manta ray conservation is to improve understanding of population distribution, abundance, trends, and structure through research, monitoring, and modeling (Stewart et al. 2018; NMFS 2020). Our preliminary presence-absence modeling approach uses distance-weighted methods to control for perception bias. With further satellite tagging data on manta ray movements and dive profiles, we may be able to address availability bias for animals that are underwater, and apply similar methods to determine population abundance. Further genetic analyses are needed to resolve the taxonomic status and relative abundance of $M$. birostris and M. sp. cf. birostris sensu (Marshall et al. 2009). More telemetry studies are also needed to evaluate whether giant manta rays within the Gulf of Mexico and northwestern Atlantic Ocean constitute one large, mixed population, or exist as isolated subpopulations (Stewart et al. 2016). Observing rare species incurs a heavy cost in time, resources, and boat fuel. Our findings suggest that bathymetric maps combined with real-time satellite data may be used to effectively target manta rays for scientific study, including the attachment of satellite tags to inform movements, site fidelity, and dive patterns. Following Farmer et al. (2018), individual impacts can then be summarized across the population to evaluate population consequences of disturbance in the context of population recovery.

\section{Declarations}

\section{Acknowledgements}

S. Kajiura and J. Waldron thank the Colgan Foundation for supporting the FAU aerial survey project. J. Pate and A. Marshall received funding for manta surveys from the Disney Conservation Fund, Kansas City Zoo and Brevard Zoo. Curation of the North Atlantic Right Whale Consortium database has been supported by the National Marine Fisheries Service, and the New England Aquarium aerial surveys in 1989-1992 were funded by the Minerals Management Service. Normandeau Associates/APEM thank NYSERDA for supporting the aerial digital survey and making these data available to us. Many thanks to 
A. Marshall, E.L. Hickerson, G. Rappucci, L.A. Dias, and J.K. Carlson for helpful reviews of this manuscript.

\section{Author Contributions}

NAF conceived the work, analyzed and interpreted the data, developed the tables and figures, and drafted the manuscript. LPG provided survey data co-developed and reviewed analytical approaches. $\mathrm{CH}$ provided data and wrote management need sections of the manuscript. MM wrote introductory sections of the manuscript. TG, RDK, MW, and JRW provided data and reviewed analytical approaches. JP, DHW, TJM, KB-H, DA, SK, and JW provided data. All authors provided substantive comments and review of the manuscript.

\section{References}

1. Adams, D. \& Amesbury, E. Occurrence of the manta ray, Manta birostris, in the Indian River Lagoon, Florida. Florida Scientist 61, 7-9 (1998).

2. Beale, C.S., Stewart, J.D., Setyawan, E., Sianipar, A.B. \& Erdmann, M.V. Population dynamics of oceanic manta rays (Mobula birostris) in the Raja Ampat Archipelago, West Papua, Indonesia, and the impacts of the El Niño-Southern Oscillation on their movement ecology. Diversity \& Distributions 25(9), 1472-1487 (2019).

3. Belkin, I.M. \& O'Reilly, J.E. An algorithm for oceanic front detection in chlorophyll and SST satellite imagery. Journal of Marine Systems 78(3), 319-326 (2009).

4. Bertolini, F. Dentatura dei selaci in rapporto con la nutrizione. Rendiconti della Reale Accademia Nazionale dei Lincei 18, 234-237 (1933).

5. Bigelow, H.B. \& Schroeder, W.C. Sawfishes, guitarfishes, skates and rays in Fishes of the Western North Atlantic, Part 2. (eds. Bigelow, H.B. \& Shroeder, W.C.) 1-514 (Memoirs of Sears Foundation for Marine Research 1, Yale University Press, 1953).

6. Blanton, J.O., Atkinson, L.P., Pietrafesa, L.J., \& Lee, T.N. The intrusion of Gulf Stream water across the continental shelf due to topographically-induced upwelling. Deep Sea Research Part A, Oceanographic Research Papers 28(4), 393-405 (1981). https://doi.org/10.1016/01980149(81)90006-6.

7. Brodie, S., Jacox, M.G., Bograd, S.J., Welch, H., Dewar, H., Scales, K.L, Maxwell, S.M., Briscoe, D.M., Edwards, C.A., Crowder, L.B., \& Lewison, R.L. Integrating dynamic subsurface habitat metrics into species distribution models. Frontiers in Marine Science 5(219), 1-13 (2018).

8. Brodle, S., Abrahms, B., Bograd, S., Carroll, G., Hazen, E., Muhling, B., Pozo Bull, M., Smith, J., Welch, H., \& Jacox, M. Exploring timescales of predictability in species distributions. Ecography 44(6), 832844 (2021).

9. Bucair, N., Venables, S.K., Balboni, A.P., \& Marshall, A.D. Sightings trends and behavior of manta rays in Fernando de Noronha Archipelago, Brazil. Marine Biodiversity Records 14, 
10; https://doi.org/10.1186/s41200-021-00204-w (2021).

10. Bumpus, D.D. \& Wehe, T.J. Hydrography of the western Atlantic: Coastal water circulation off the east coast of the United States between Cape Hatteras and Florida. Technical Report No. 16. Woods Hole Oceanographic Institution, Woods Hole, Massachusetts (1949).

11. Burgess, K. Feeding ecology and habitat use of the giant manta ray Manta birostris at a key aggregation site off mainland Ecuador. PhD Thesis, Faculty of Medicine, The University of Queensland. https://doi.org/10.14264/uql.2018.157 (2017).

12. Carlson, J.K. Estimated incidental take of smalltooth sawfish (Pristis pectinata) and giant manta ray (Manta birostris) in the South Atlantic and Gulf of Mexico shrimp trawl fishery. Panama City Laboratory Contribution Series 20-03. National Marine Fisheries Service, Panama City, Florida (2020).

13. Carpenter, K.E. \& Niem, V.H. FAO species identification guide for fishery purposes. The living marine resources of the Western Central Pacific. Volume 5: Bony fishes part 3 (Menidae to Pomacentridae). Food and Agriculture Organization of the United Nations, Rome, Italy (2001).

14. Chamberlain, S. rerddap: General Purpose Client for 'ERDDAP' Servers. R package version 0.7.4. https://cran.r-project.org/package=rerddap (2021).

15. Childs, J.N. The Occurrence, Habitat Use and Behavior of Sharks and Rays Associating with Topographic Highs in the Gulf of Mexico. M.S. Thesis. Texas A\&M University, College Station, Texas (2001).

16. [CITES] Convention on International Trade in Endangered Species of Wild Fauna and Flora. Consideration of proposals for amendment of Appendices I and II. Sixteenth meeting of the Conference of the Parties, Bangkok (Thailand), 3-14 March 2013. Conference document CoP16 Prop. 46 (Rev.2). CITES, Geneva, Switzerland (2013).

17. Clark, T.B. Abundance, home range, and movement patterns of manta rays (Manta alfredi, $M$. birostris) in Hawai'i. Ph.D. dissertation, Dept. of Zoology, University of Hawaii, Manoa, Hawaii (2010).

18. Couturier, L.I., Marshall, A.D., Jaine, F.R., Kashiwagi, T., Pierce, S.J., Townsend, K.A., Weeks, S.J., Bennett, M.B. \& Richardson, A.J. Biology, ecology and conservation of the Mobulidae. Journal of Fish Biology 80, 1075-1119 (2012). doi 10.1111/j.1095-8649.2012.03264.x

19. Croll, D.A., Dewar, H., Dulvy, N.K., Fernando, D., Francis, M.P., Galván-Magaña, F., Hall, M., Heinrichs, S., Marshall, A., McCauley, D., Newton, K.M., Notarbartolo-Di-Sciara, G., O'Malley, M., O'Sullivan, J., Poortvliet, M., Roman, M., Stevens, G., Tershy, B.R. \& White, W.T. Vulnerabilities and fisheries impacts: the uncertain future of manta and devil rays. Aquatic Conservation: Marine and Freshwater Ecosystems 26(3), 562-575 (2015). doi 10.1002/aqc.2591

20. Deutsch, C.A., Tewksbury, J.J., Huey, R.B., Sheldon, K.S., Ghalambor, C.K., Haak, D.C. \& Martin, P.R. Impacts of climate warming on terrestrial ectotherms across latitude. Proceedings of the National Academy of Sciences of the USA 105, 6668-6672 (2008). https ://doi.org/10.1073/pnas.07094 72105

21. Duffy, C.A.J. \& Abbott, D. Sightings of mobulid rays from northern New Zealand, with confirmation of the occurrence of Manta birostris in New Zealand waters. New Zealand Journal of Marine and 
Freshwater Research 37, 715-721 (2003). doi <Go to ISI>://WOS:000187604400004

22. Essumang, D.K. First determination of the levels of platinum group metals in Manta birostris (manta ray) caught along the Ghanaian coastline. Bulletin of Environmental Contamination and Toxicology 84, 720-725 (2010). https://doi.org/10.1007/s00128-010-0019-8

23. Farmer, N.A., Gowan, T.A., Powell, J.R. \& Zoodsma, B.J. Evaluation of alternatives to winter closure of black sea bass pot gear: Projected impacts on catch and risk of entanglement with North Atlantic right whales Eubalaena glacialis. Marine and Coastal Fisheries 8(1), 202-221 (2016). DOI:

10.1080/19425120.2016.1146181

24. Farmer, N.A., Heyman, W.D., Karnauskas, M., Kobara, S., Smart, T., Ballenger, J., Reichert, M., Wyanski, D., Tishler, M.S., Lindeman, K.C., Lowerre-Barbieri, S., Switzer, T., Solomon, J., McCain, K., Marhefka, M. \& Sedberry, G.R. Timing and location of reef fish spawning activity in the Atlantic Ocean off the southeastern United States. PLoS ONE 12(3), e0172968 (2017).

25. Farmer, N.A., Baker, K., Zeddies, D.G., Denes, S.L., Noren, D.P., Garrison, L.P., Machernis, A., Fougères, E.M. \& Zykov, M. Population consequences of disturbance by offshore oil and gas activity for endangered sperm whales (Physeter macrocephalus). Biological Conservation 227, 189-204 (2018).

26. Freedman, R. \& Roy, S.S. Spatial patterning of Manta birostris in United States east coast offshore habitat. Applied Geography 32, 652-665 (2012).

27. Garrison, L.P. Abundance of coastal and continental shelf stocks of bottlenose dolphins in the northern Gulf of Mexico: 2011-2012. Protected Resources and Biodiversity Division Report, PRD2017-04. National Marine Fisheries Service, Southeast Fisheries Science Center, Miami, Florida (2017).

28. Garrison, L.P., Ortega-Ortiz, J. \& Rappucci, G. Abundance of coastal and continental shelf stocks of bottlenose dolphins in the northern Gulf of Mexico: 2017-2018. Protected Resources and Biodiversity Division Report, PRD-2021-01. National Marine Fisheries Service, Southeast Fisheries Science Center, Miami, Florida (2021).

29. Garzon, F., Graham, R.T., Witt, M.J. \& Hawkes, L.A. Ecological niche modeling reveals manta ray distribution and conservation priority areas in the Western Central Atlantic. Animal Conservation 24(3), 322-334 (2020). doi:10.1111/acv.12663

30. Germanov, E.S., Marshall, A.D., Hendrawan, I.G., Admiraal, R., Rohner, C.A., Argeswara, J., Wulandari, R., Himawan, M.R. \& Loneragan, N.R. Microplastics on the menu: Plastics pollute Indonesian manta ray and whale shark feeding grounds. Frontiers in Marine Science 6(679), 1-21 (2019) . https://doi.org/10.3389/fmars.2019.00679

31. Gilchrist, G.W. Specialists and generalists in changing environments. I. Fitness landscapes of thermal sensitivity. American Naturalist 146, 252-270 (1995). https ://doi.org/10.1086/28579

32. Graham, R.T., Witt, M.J., Castellanos, D.W., Remolina, F., Maxwell, S., Godley, B.J. \& Hawkes, L.A. Satellite tracking of manta rays highlights challenges to their conservation. PLoS ONE 7(5), e36834 (2012). 10.1371/journal.pone.0036834 
33. Gudger, E.W. The most northerly record of the capture in Atlantic waters of the United States of the giant ray, Manta birostris. Science 55(1422), 338-340 (1922).

34. Guinder, V.A. \& Molinero, J.C. Climate change effects on marine phytoplankton in Marine Ecology in a Changing World (eds. Arias, A.H. \& Menendez, M.C.) 68-90 (CRC Press, Boca Raton, Florida, 2013). doi 10.1201/b16334-4

35. Hacohen-Domené, A., Martínez-Rincón, R.O., Galván-Magaña, F., Cárdenas-Palomo, N. \& HerreraSilveira, J. Environmental factors influencing aggregation of manta rays (Manta birostris). Marine Ecology 38(3), e12432 (2017).

36. Hazen, E.L., Palacios, D.M., Forney, K.A., Howell, E.A., Becker, E., Hoover, A.L., Irvine, L., DeAngelis, M., Bograd, S.J., Mate, B.R. \& Bailey, H. WhaleWatch: a dynamic management tool for predicting blue whale density in the California Current. Journal of Applied Ecology 54(5), 1415-28 (2017).

37. Heyman, W.D., Grüss, A., Biggs, C., Kobara, S., Farmer, N., Karnauskas, M., Lowerre-Barbieri, S. \& Erisman, B. Cooperative monitoring, assessment, and management of fish spawning aggregations and associated fisheries in the U.S. Gulf of Mexico. Marine Policy 109, 103689 (2019).

38. Hinojosa-Alvarez, S., Walter, R.P., Diaz-Jaimes, P., Galván-Magaña, F., Paig-Tran, E.M. A potential third manta ray species near the Yucatán Peninsula? Evidence for a recently diverged and novel genetic Manta group from the Gulf of Mexico. PeerJ 4, e2586 (2016). doi: 10.7717/peerj.2586

39. Homma, K., Maruyama, T., Itoh, T., Ishihara, H. \& Uchida, S. Biology of the manta ray, Manta birostris Walbaum, in the Indo-Pacific. Proceedings of the 5th Indo-Pacific Fish Conference, 209216. doi <Go to ISI ://WOS:000084731300021

40. Hosegood, J., Humble, E., Ogden, R., de Bruyn, M., Creer, S., Stevens, G., Abudaya, M., Bassos-Hull, K., Bonfil, R., Fernando, D., Foote, A.D., Hipperson, H., Jabado, R.W., Kaden, J., Moazzam, M., Peel, L., Pollett, S., Ponzo, A., Poortvliet, M., Salah, J., Senn, H., Stewart, J., Wintner, S. \& Carvalho, G. Phylogenomics and species delimitation for effective conservation of manta and devil rays. Molecular Ecology 29(24), 4783-4796 (2020). doi: 10.1111/mec.15683

41. Huey, R.B., Kingsolver, J.G. Evolution of thermal sensitivity of ectotherm performance. Trends in Ecology and Evolution 4, 131-135 (1989). https ://doi.org/10.1016/0169-5347(89)90211 -5

42. Johnston, M.A., Sterne, T.K., Blakeway, R.D., MacMillan, J., Nuttall, M.F., Hu, X., Embesi, J.A., Hickerson, E.L. \& Schmahl, G.P. Long-term monitoring at east and west Flower Garden Banks: 2017 annual report. Marine Sanctuaries Conservation Series ONMS-18-02. Flower Garden Banks National Marine Sanctuary, Galveston, Texas (2018).

43. Kamykowski, D. \& Zentara, J. Changes in world ocean nitrate availability through the 20th century. Deep Sea Research I 52, 1719-1744 (2005).

44. Kashiwagi, T. Conservation biology and genetics of the largest living rays: manta rays. Ph.D. dissertation. School of Biomedical Sciences, University of Queensland, Brisbane, Australia (2014).

45. Kashiwagi, T., Ito, T. \& Sato, F. Occurrences of reef manta ray, Manta alfredi, and giant manta ray, $M$. birostris, Japan, examined by photographic records. Report of Japanese Society for Elasmobranch Studies 46: 20-27 (2010). 
46. Kashiwagi, T., Marshall, A., Corrigan, S., Dove, A., da la Parra Venegas, R., Naylor, G. \& Heist, E. Are there DNA evidences for the new species of manta ray? Meeting of Ichthyologists and Herpetologists, American Elasmobranch Society. Austin, Texas (2017).

47. Kashiwagi, T., Marshall, A.D., Bennett, M.B. \& Ovenden, J.R. Habitat segregation and mosaic sympatry of the two species of manta ray in the Indian and Pacific Oceans: Manta alfredi and $M$. birostris. Marine Biodiversity Records 4, e86 (2011).

48. Kingsolver, J.G. The well-temperatured biologist. American Naturalist 174, 755-768 (2009). https ://doi.org/10.1086/648310

49. Kitchen-Wheeler, A-M. The behaviour and ecology of Alfred mantas (Manta alfredi) in the Maldives. Ph.D. Thesis, Newcastle University, Newcastle upon Tyne, England (2013). Available online: http://hdl.handle.net/10443/1936

50. Laake, J.L. \& Borchers, D.L. Methods for incomplete detection at distance zero in Advanced distance sampling. (eds. Buckland, S.T., Andersen, D.R., Burnham, K.P., Laake, J.L. \& Thomas, L.) 108-189 (Oxford University Press, New York, 2004).

51. Laake, J., Borchers, D., Thomas, L., Miller, D. \& Bishop, J. mrds: Mark-Recapture Distance Sampling. R package version 2.2.2 (2020). https://CRAN.R-project.org/package=mrds

52. Lau-Medrano, W. grec: GRadient-Based RECognition of Spatial Patterns in Environmental Data. R package version 1.3.1 (2020). https://github.com/LuisLauM/grec

53. Lear, K.O., Whitney, N.M., Morgan, D.L., Brewster, L.R., Whitty, J.M., Poulakis, G.R., Scharer, R.M., Guttridge, T.L. \& Gleiss, A.C. Thermal performance responses in free-ranging elasmobranchs depend on habitat use and body size. Oecologia 191(4), 829-842 (2019). https://doi.org/10.1007/s00442019-04547-1

54. Luiz, O.J., Balboni, A.P., Kodja, G., Andrade, M. \& Marum, H. Seasonal occurrences of Manta birostris (Chondrichthyes: Mobulidae) in southeastern Brazil. Ichthyological Research 56, 96-99 (2009). doi 10.1007/s10228-008-0060-3

55. Marshall, A.D., Compagno, L.J. \& Bennett, M.B. Redescription of the genus Manta with resurrection of Manta alfredi (Krefft, 1868) (Chondrichthyes; Myliobatoidei; Mobulidae). Zootaxa 2301, 1-28 (2009).

56. McCauley, D.J., DeSalles, P.A., Young, H.S., Papastamatiou, Y.P., Caselle, J.E., Deakos, M.H., Gardner, J.P., Garton, D.W., Collen, J.D. \& Micheli, F. Reliance of mobile species on sensitive habitats: a case study of manta rays (Manta alfredi) and lagoons. Marine Biology 161, 1987-1998 (2014).

57. Medeiros, A.M., Luiz, O.J. \& Domit, C. Occurrence and use of an estuarine habitat by giant manta ray Manta birostris. Journal of Fish Biology 86, 1830-1838 (2015). doi 10.1111/jfb.12667

58. Milessi, A.C. \& Oddone, M.C. Primer registro de Manta birostris (Donndorff 1798) (Batoidea: Mobulidae) en el Rio de La Plata, Uruguay. Gayana 67, 126-129 (2003).

59. Miller, D.L., Rexstad, E., Thomas, L., Marshall, L. \& Laake, J.L. Distance sampling in R. Journal of Statistical Software 89(1), 1-28 (2019). doi: 10.18637/jss.v089.i01 (URL: https://doi.org/10.18637/jss.v089.i01). 
60. Miller, M.H. \& Klimovich, C. Endangered Species Act status review report: Giant manta ray (Manta birostris) and reef manta ray (Manta alfredi). National Marine Fisheries Service, Office of Protected Resources, Silver Spring, Maryland (2017).

61. Moore, A.B.M. Records of poorly known batoid fishes from the north-western Indian Ocean (Chondrichthyes: Rhynchobatidae, Rhinobatidae, Dasyatidae, Mobulidae). African Journal of Marine Science 34, 297-301 (2012). doi 10.2989/1814232X.2012.675129

62. Mourier, J. Manta rays in the Marquesas Islands: first records of Manta birostris in French Polynesia and most easterly location of Manta alfredi in the Pacific Ocean, with notes on their distribution. Journal of Fish Biology 81, 2053-2058 (2012). doi 10.1111/j.1095-8649.2012.03449.x

63. [NOAA] National Oceanographic and Atmospheric Administration Fisheries Service Final Rule To List the Giant Manta Ray as Threatened Under the Endangered Species Act. Federal Register 83, 29162931 (2018).

64. [NOAA] National Oceanographic and Atmospheric Administration Fisheries Service Determination on the Designation of Critical Habitat for Giant Manta Ray. Federal Register 84, 66652-66664 (2019).

65. [NOAA] National Oceanographic and Atmospheric Administration Fisheries Service. Giant manta ray recovery outline. Office of Protected Resources https://www.fisheries.noaa.gov/resource/document/giant-manta-ray-recovery-outline (2020).

66. North Atlantic Right Whale Consortium. North Atlantic Right Whale Consortium sightings database. https://www.narwc.org/accessing-narwc-data.html (2018).

67. Notarbartolo-di-Sciara, G. \& Hillyer, E.V. Mobulid rays off eastern Venezuela (Chondrichthyes, Mobulidae). Copeia 1989(3), 607-614 (1989).

68. Ooi, M.S., Townsend, K.A., Bennett, M.B., Richardson, A.J., Fernando, D., Villa, C.A., et al. Levels of arsenic, cadmium, lead and mercury in the branchial plate and muscle tissue of mobulid rays. Marine Pollution Bulletin 94, 251-259 (2015). doi: 10.1016/j.marpolbul.2015.02.005.

https://doi.org/10.1016/j.marpolbul.2015.02.005

69. Palka, D.L., Chavez-Rosales, S., Josephson, E., Cholewiak, D., Haas, H.L., Garrison, L.P., Jones, M., Sigourney, D., Waring, G., Jech, M., Broughton, E., Soldevilla, M., Davis, G., DeAngelis, A., Sasso, C.R., Winton, M.V., Smolowitz, R.J., Fay, G., LaBrecque, E., Leiness, J.B., Dettloff, K., Warden, M., Murray, K. \& Orphanides, C. Atlantic Marine Assessment Program for Protected Species: 2010-2014. OCS Study BOEM 2017-071. US Dept. of the Interior, Bureau of Ocean Energy Management, Atlantic OCS Region, Washington, DC (2017).

70. Pante, E. \& Simon-Bouhet, B. marmap: A package for importing, plotting and analyzing bathymetric and topographic data in R. PLoS ONE 8(9), e73051 (2013). doi:10.1371/journal.pone.0073051

71. Pate, J.H., Macdonald, C. \& Wester, J. Surveys of recreational anglers reveal knowledge gaps and positive attitudes towards manta ray conservation in Florida. Aquatic Conservation: Marine and Freshwater Ecosystems 31(6), 1410-1419 (2021). https://doi.org/10.1002/aqc.3508

72. Pate, J.H. \& Marshall, A.D. Urban manta rays: potential manta ray nursery habitat along a highly developed Florida coastline. Endangered Species Research 43, 51-64 (2020). 
73. Poortvliet, M., Olsen, J.L., Croll, D.A., Bernardi, G., Newton, K., Kollias, S., O'Sullivan, J., Fernando, D., Stevens, G., Magana, F.G., Seret, B., Wintner, S. \& Hoarau, G. A dated molecular phylogeny of manta and devil rays (Mobulidae) based on mitogenome and nuclear sequences. Molecular Phylogenetics and Evolution 83, 72-85 (2015). doi 10.1016/j.ympev.2014.10.012

74. Record, N.R., Runge, J.A., Pendleton, D.E., Balch, W.M., Davies, K.T.A., Pershing, A.J., Johnson, C.L., Stamieszkin, K., Ji, R., Feng, Z., Kraus, S.D. , Kenney, R.D., Hudak, C.A., Mayo, C.A., Chen, C., Salisbury, J.E. \& Thompson, C.R.S. Rapid climate-driven circulation changes threaten conservation of endangered North Atlantic right whales. Oceanography 32(2), 162-169 (2019).

75. Richardson, A.J. In hot water: zooplankton and climate change. ICES Journal of Marine Science 65(3), 279-295 (2008). https://doi.org/10.1093/icesjms/fsn028

76. Roberts, B. Cobia and the rays. Florida Sportsman http://www.floridasportsman.com/2020/11/08/cobia-rays/ (2020).

77. Robin, X., Turck, N., Hainard, A., Tiberti, N., Lisacek, F., Sanchez, J.C. \& Müller, M. pROC. an opensource package for $\mathrm{R}$ and $\mathrm{S}+$ to analyze and compare ROC curves. BMC Bioinformatics 12, 77 (2011). DOI: 10.1186/1471-2105-12-77 <http://www.biomedcentral.com/1471-2105/12/77/>

78. Rohner, C.A., Burgess, K.B., Rambahiniarison, J.M., Stewart, J.D., Ponzo, A., Richardson, A.J. Mobulid rays feed on euphausiids in the Bohol Sea. Royal Society Open Science 4, 161060 (2017). doi $10.1098 /$ rsos. 161060

79. Romanov, E. Mobulidae of the Indian Ocean: an identification hints for field sampling, draft, version 2.1, August. IOTC Working Party on Ecosystems and Bycatch, Victoria, Seychelles, 27-30 October 2010 (Indian Ocean Tuna Commission, Food and Agriculture Organization of the United Nations, Rome, Italy, 2010).

80. Schulte, P.M., Healy, T.M. \& Fangue, N.A. Thermal performance curves, phenotypic plasticity, and the time scales of temperature exposure. Integrative and Comparative Biology 51, 691-702 (2011). https ://doi.org/10.1093/icb/icr097

81. Shropshire, T.A., Morey, S.L., Chassignet, E.P., Bozec, A., Coles, V.J., Landry, M.R., Swalethorp, R., Zapfe, G., Stukel, M.R. Quantifying spatiotemporal variability in zooplankton dynamics in the Gulf of Mexico with a physical-biogeochemical model. Biogeosciences 17(13), 3385-3407 (2020).

82. Shumway, R.H. \& Stoffer, D.S. Time series analysis and its applications: with R examples (4th ed). Springer Texts in Statistics (Springer International Publishing, Cham, Switzerland, 2017).

83. Stewart, J.D., Beale, C.S., Fernando, D., Sianipar, A.B., Burton, R.S., Semmens, B.X. \& Aburto-Oropeza, 0 . Spatial ecology and conservation of Manta birostris in the Indo-Pacific. Biological Conservation 200, 178-183 (2016). doi 10.1016/j.biocon.2016.05.016

84. Stewart, J.D., Jaine, F.R., Armstrong, A.J., Armstrong, A.O., Bennett, M.B., Burgess, K.B., Couturier, L.I., Croll, D.A., Cronin, M.R., Deakos, M.H. \& Dudgeon, C.L. Research priorities to support effective manta and devil ray conservation. Frontiers in Marine Science 5, 314 (2018).

85. Stewart, J.D., Rohner, C.A., Araujo, G., Avila, J., Fernando, D., Forsberg, K., Ponzo, A., Rambahiniarison, J.M., Kurle, C.M. \& Semmens, B.X. Trophic overlap in mobulid rays: insights from stable isotope 
analysis. Marine Ecology Progress Series 580, 131-151 (2017). doi 10.3354/meps12304

86. Stewart, J.D., Nuttall, M. \& Hickerson, E.L. Important juvenile manta ray habitat at Flower Garden Banks National Marine Sanctuary in the northwestern Gulf of Mexico. Marine Biology 165, 111 (2018). https://doi.org/10.1007/s00227-018-3364-5

87. Stoffer, D. astsa: Applied Statistical Time Series Analysis. R package version 1.12. https://CRAN.Rproject.org/package=astsa (2020).

88. Strömberg, K.P., Smyth, T.J., Allen, J.I., Pitois, S. \& O'Brien, T.D. Estimation of global zooplankton biomass from satellite ocean colour. Journal of Marine Systems 78(1), 18-27 (2009).

89. Tett, P., Crisp, D. \& Fogg, G. Modelling phytoplankton production at shelf-sea fronts [and discussion]. Philosophical Transactions of the Royal Society of London, Series A, Mathematical and Physical Sciences 302(1472), 605-615 (1981). Retrieved August 13, 2020, from www.jstor.org/stable/37041

90. [USCG] United States Coast Guard. 2019 recreational boating statistics. COMDTPUB P16754.33. U.S. Department of Homeland Security, U.S. Coast Guard, Office of Auxiliary and Boating Safety, 83 pp. https://www.uscgboating.org/library/accident-statistics/Recreational-Boating-Statistics2019.pdf (2019).

91. White, W.T., Corrigan, S., Yang, L., Henderson, A.C., Bazinet, A.L., Swofford, D.L. \& Naylor, G.J.P. Phylogeny of the manta and devilrays (Chondrichthyes: Mobulidae), with an updated taxonomic arrangement for the family. Zoological Journal of the Linnean Society of London 182(1), 50-75 (2017). doi https://doi.org/10.1093/zoolinnean/zlx018

92. Wood, S.N. Fast stable restricted maximum likelihood and marginal likelihood estimation of semiparametric generalized linear models. Journal of the Royal Statistical Society (B) 73(1), 3-36 (2011).

\section{Figures}




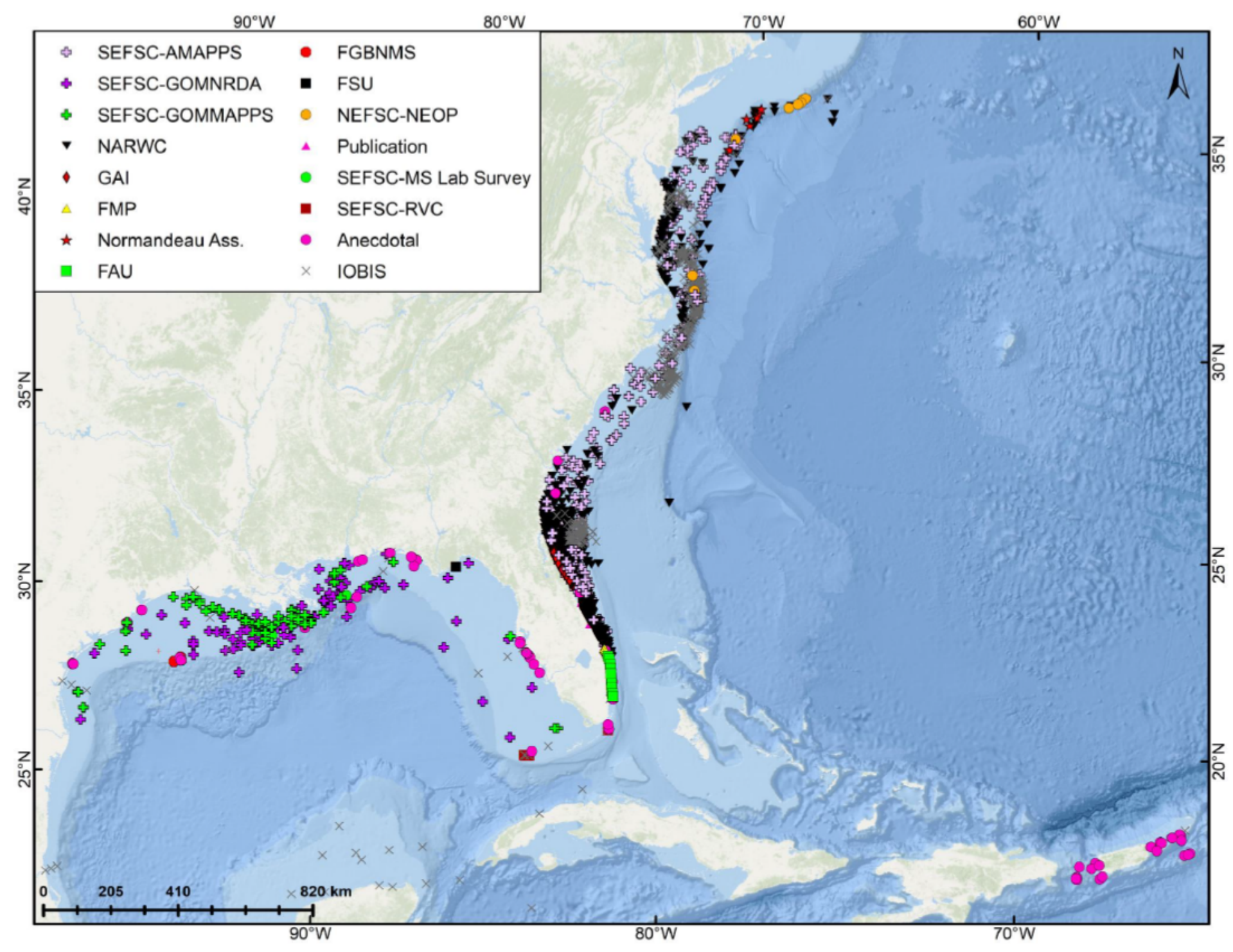

Figure 1

Reported sightings of giant manta ray from all sources 1925-2020 (see Table 1). 
A
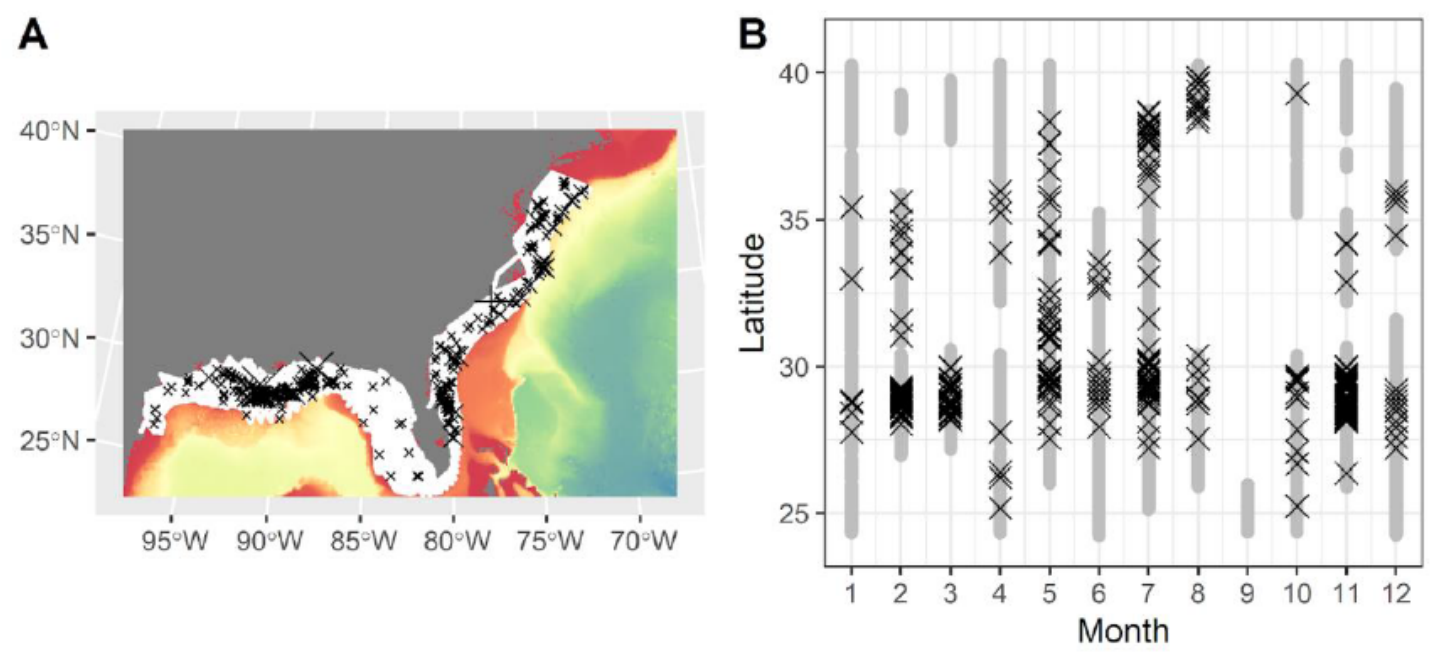

C

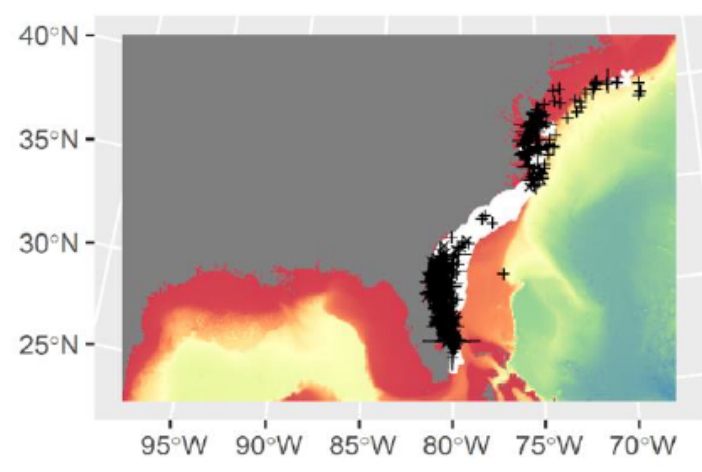

E

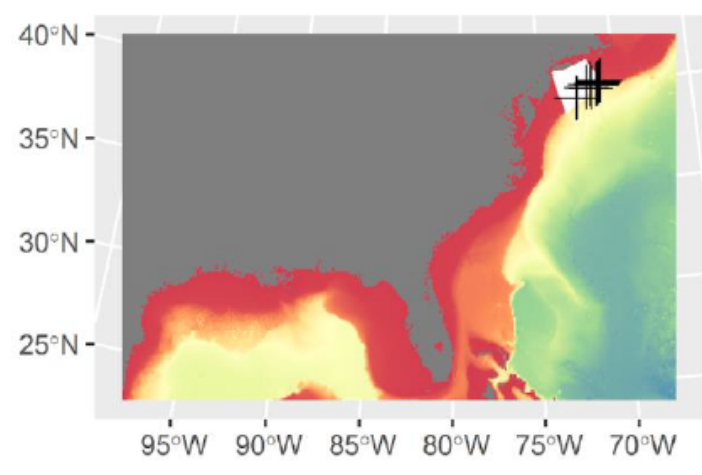

D

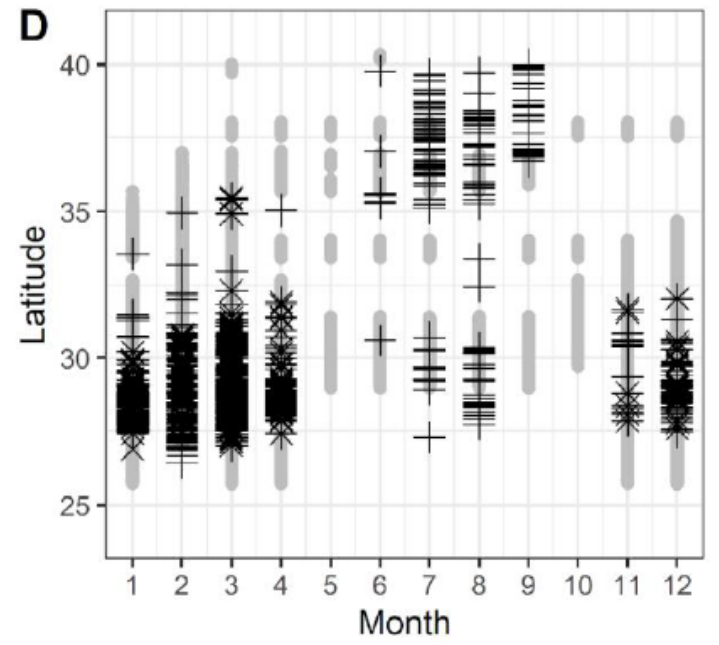

$\mathrm{F}$

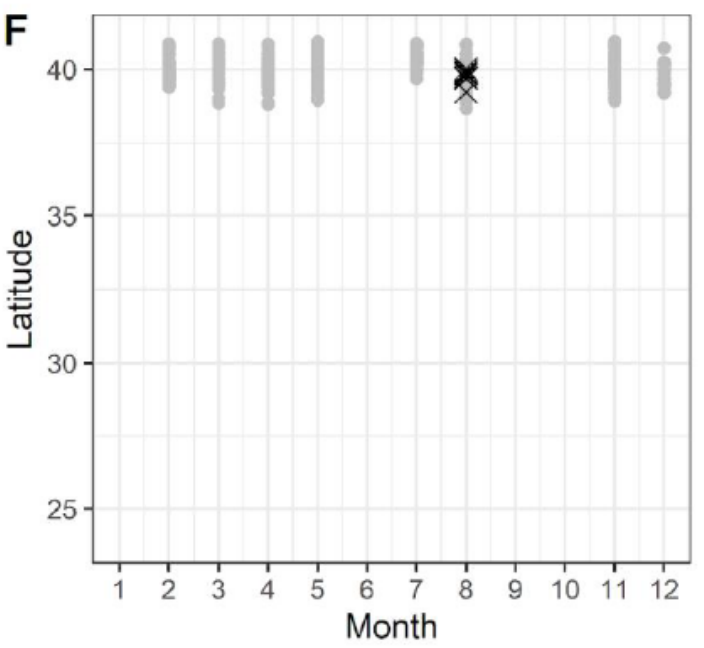

\section{Figure 2}

A) Spatial distribution relative to coarse-scale bathymetry (red=shallow; blue=deep) and survey effort (white lines) and B) spatio-temporal distribution of survey effort (gray circles) and manta ray sightings (X: on effort, + : off effort; scaled to number reported within survey) by Southeast Fisheries Science Center (SEFSC), (C,D ) North Atlantic Right Whale Consortium (NARWC), and (E,F) Normandeau Associates aerial surveys for New York State Energy Research and Development Authority (NYSERDA). 

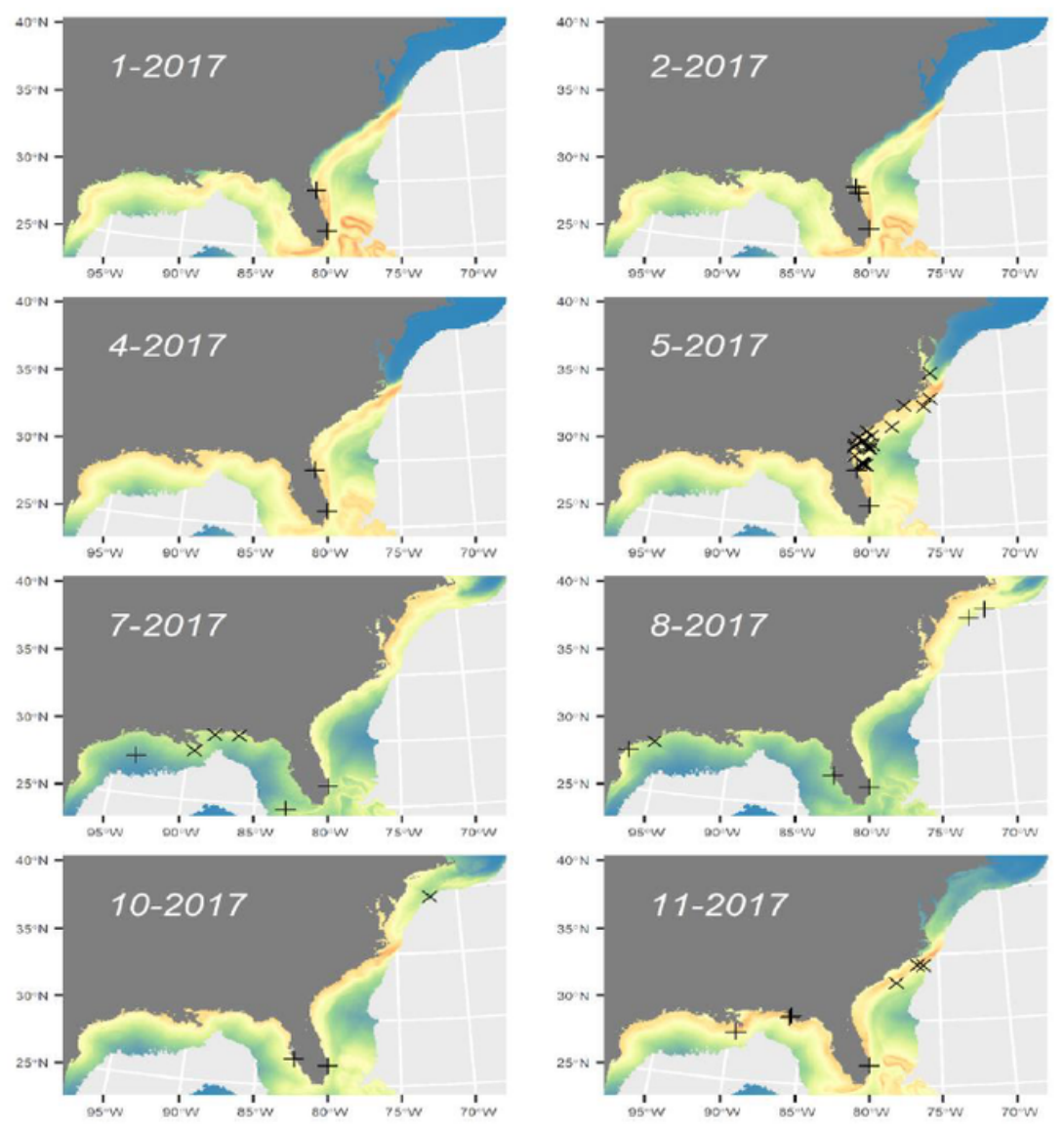
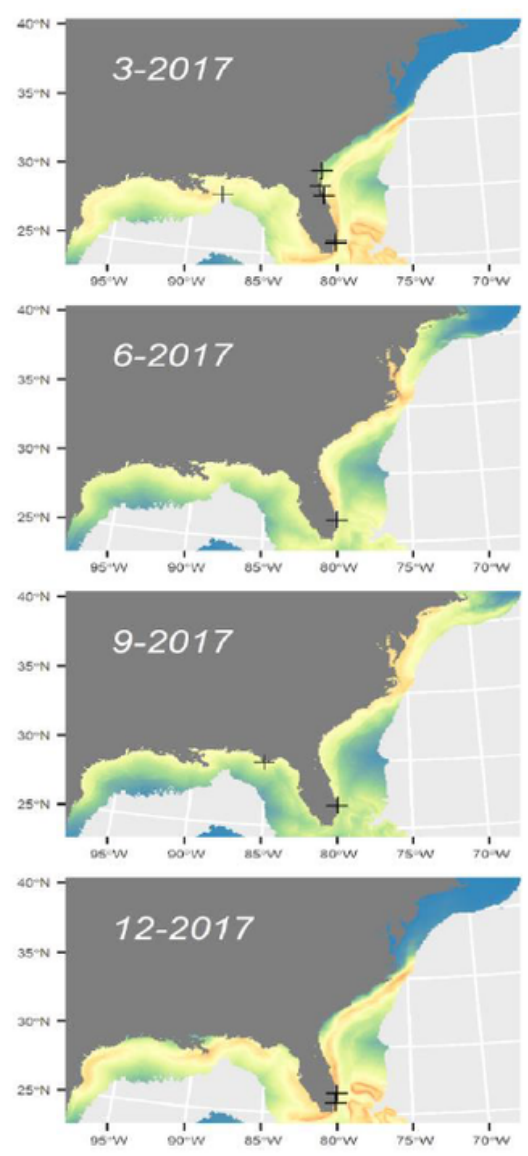

$\mathrm{P}($ Occurrence $)$

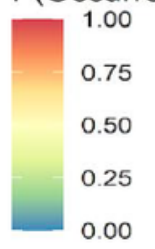

\section{Figure 3}

Predicted probability of occurrence for manta rays by SEFSC surveys for monthly average environmental conditions in 2017 with overlay of internal $(X)$ and external $(+)$ validation points. 

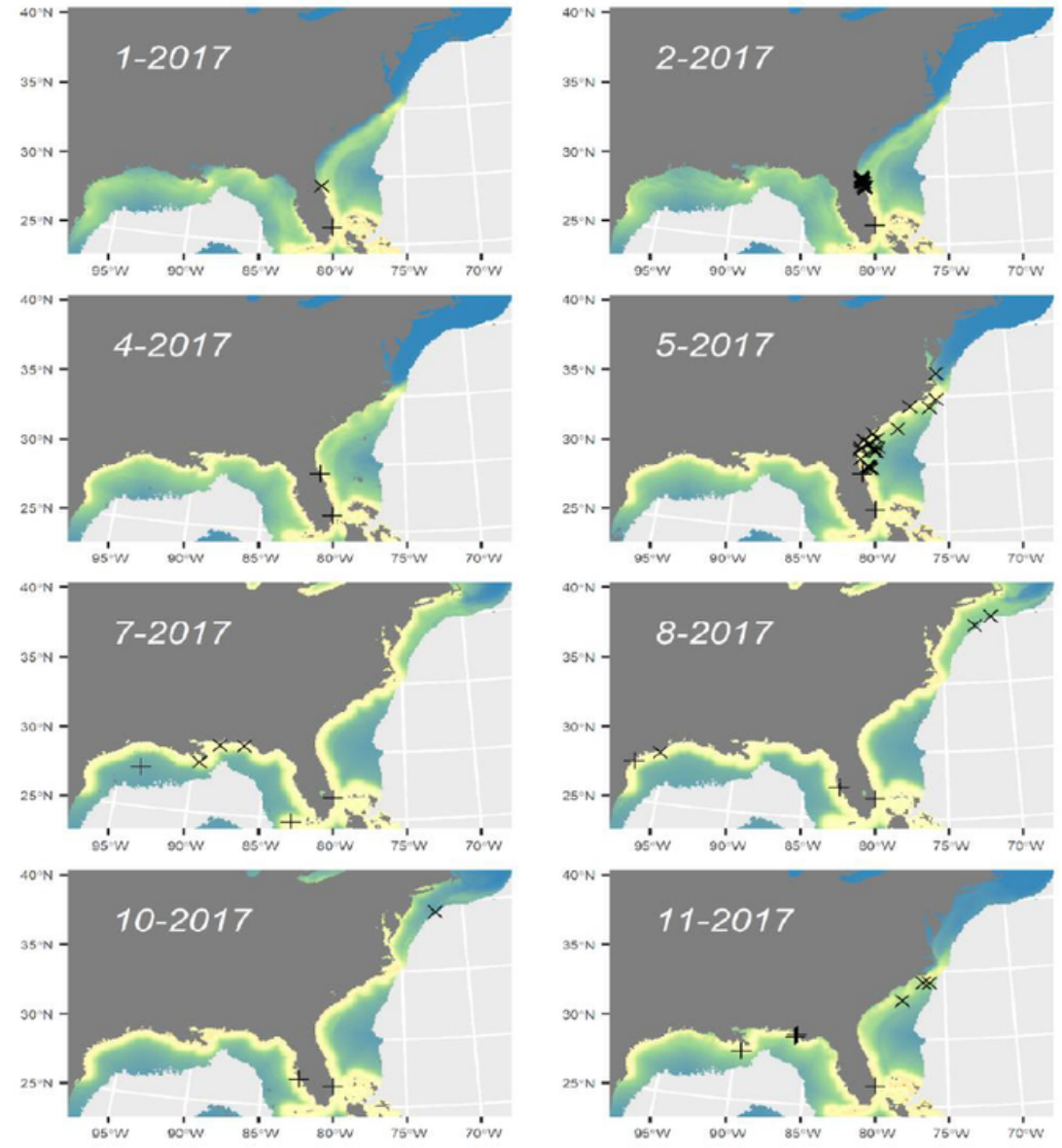
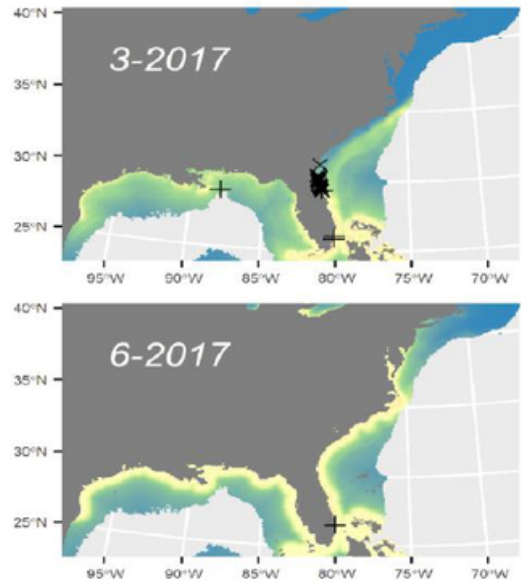

$\mathrm{P}($ Occurrence $)$
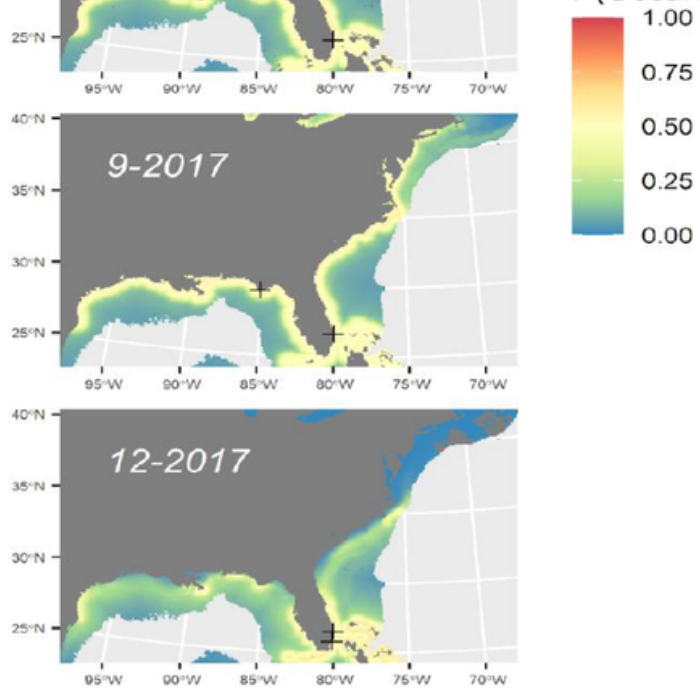

\section{Figure 4}

Predicted probability of occurrence for manta rays by a weighted ensemble of model predictions from SEFSC, NARWC, and NYSERDA surveys for monthly average environmental conditions in 2017 with overlay of internal $(\mathrm{X})$ and external $(+)$ validation points. 

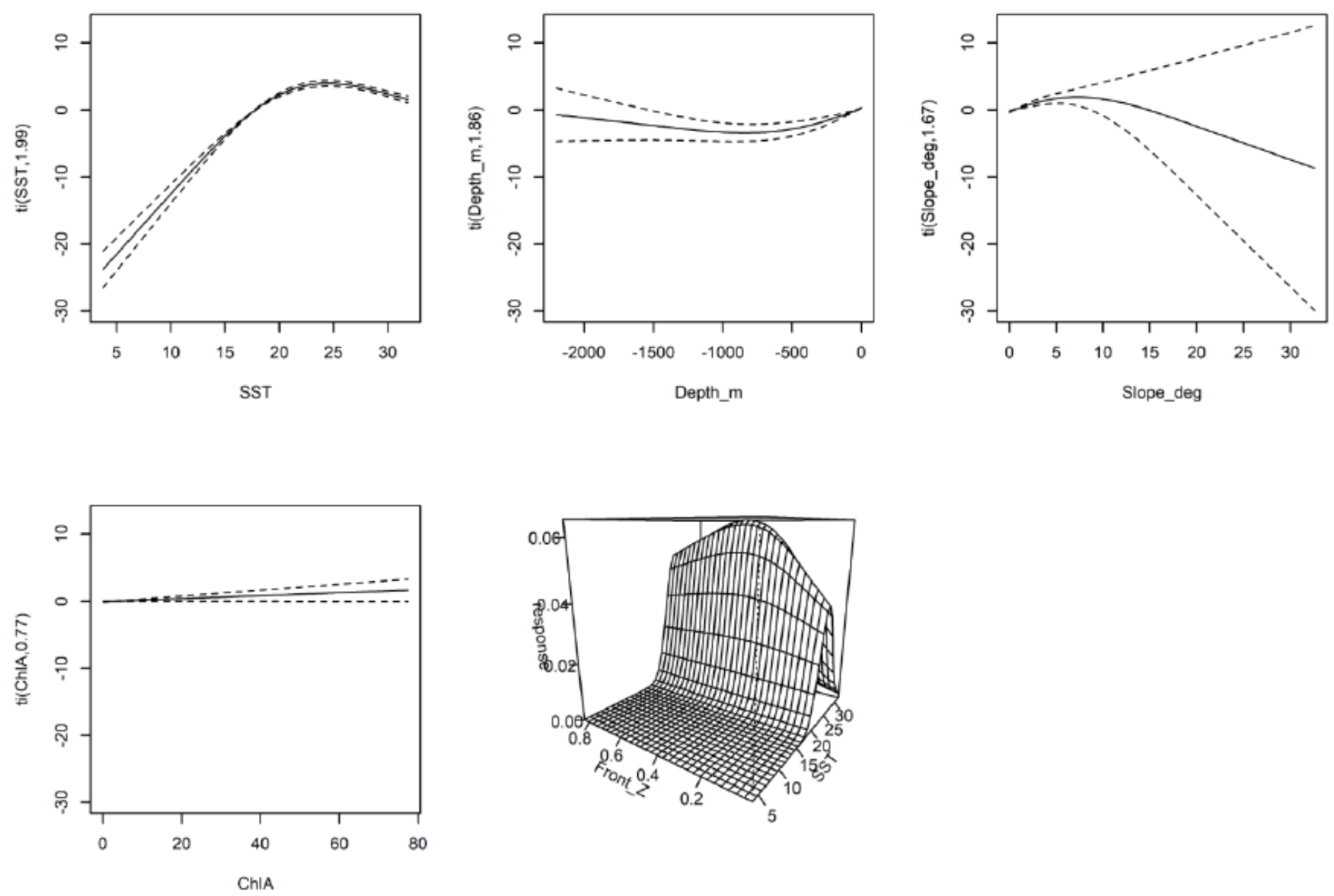

\section{Figure 5}

Significant species distribution model GAM predictor terms for combined surveys (SEFSC, NARWC, and NYSERDA) model, including sea surface temperature (SST), Z-transformed SST frontal gradients (Front_Z), depth (Depth_m), Chlorophyll-a concentrations (ChIA), and bathymetric slope (Slope_deg). 

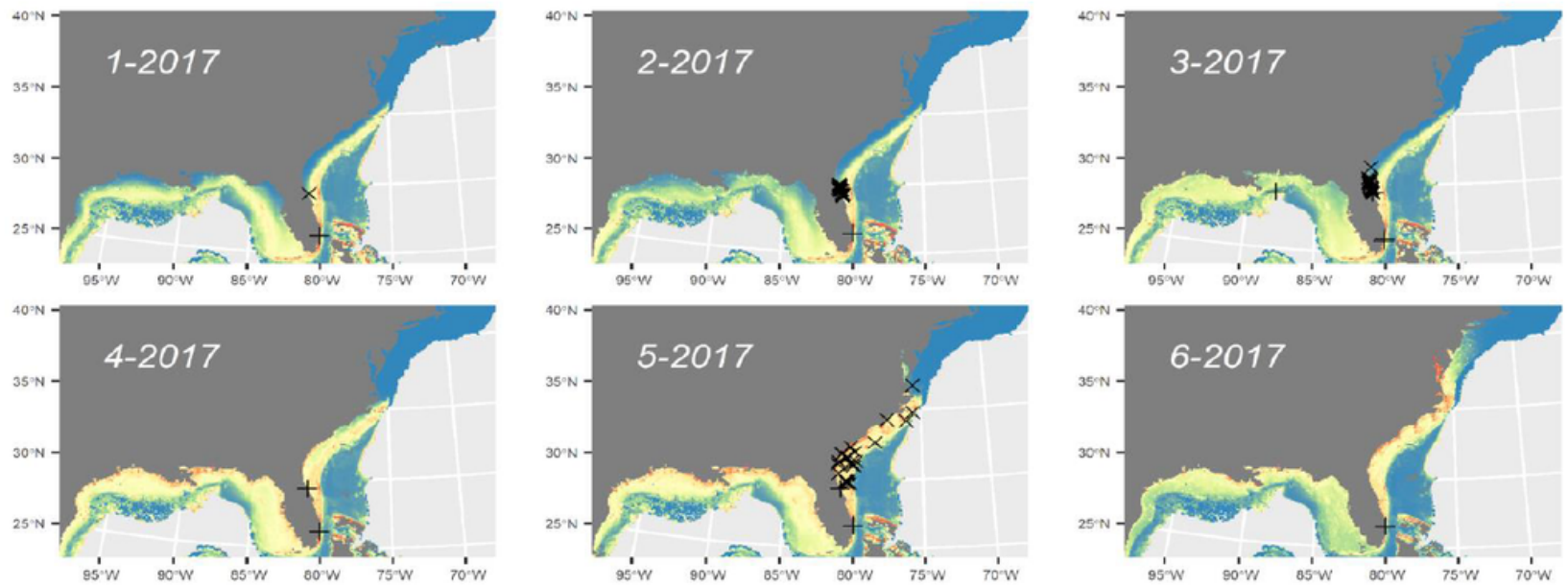

$\mathrm{P}($ Occurrence $)$
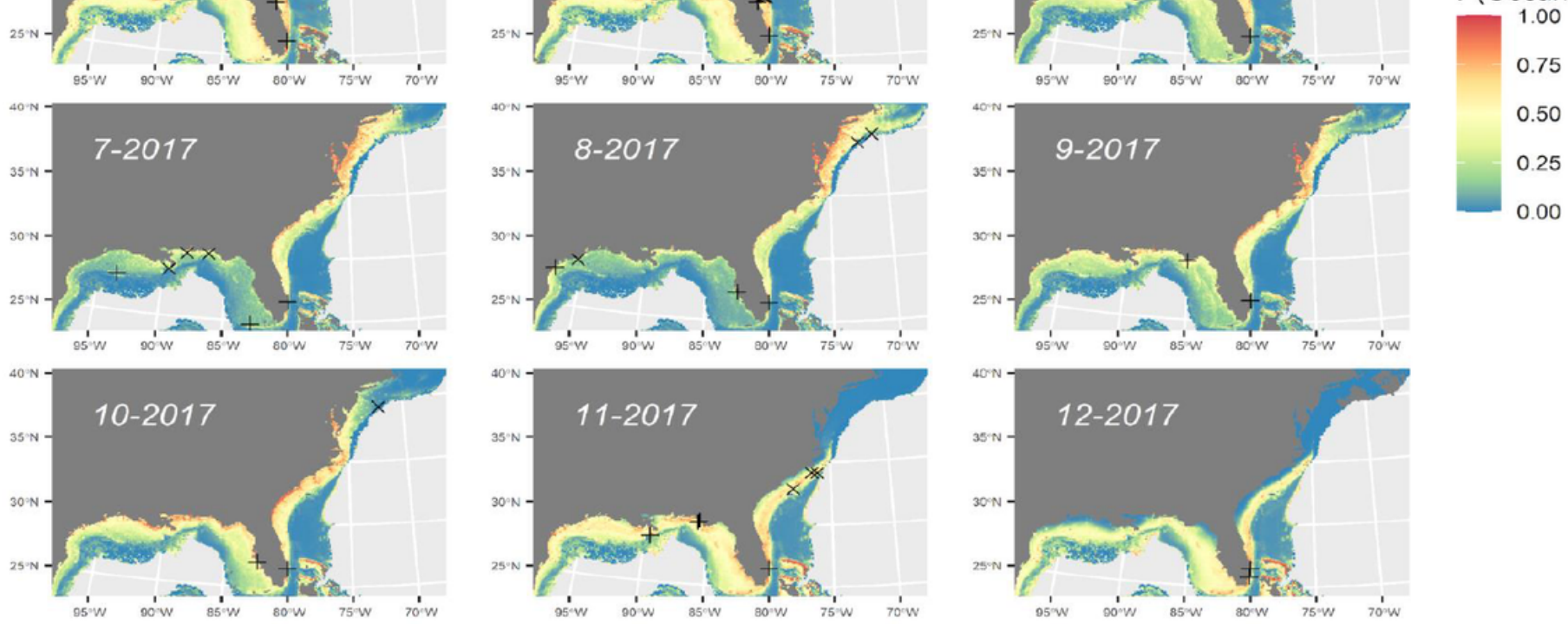

Figure 6

Predicted probability of occurrence for manta rays for combined surveys (SEFSC, NARWC, and NYSERDA) model for monthly average environmental conditions in 2017 with overlay of internal (X) and external $(+)$ validation points. 

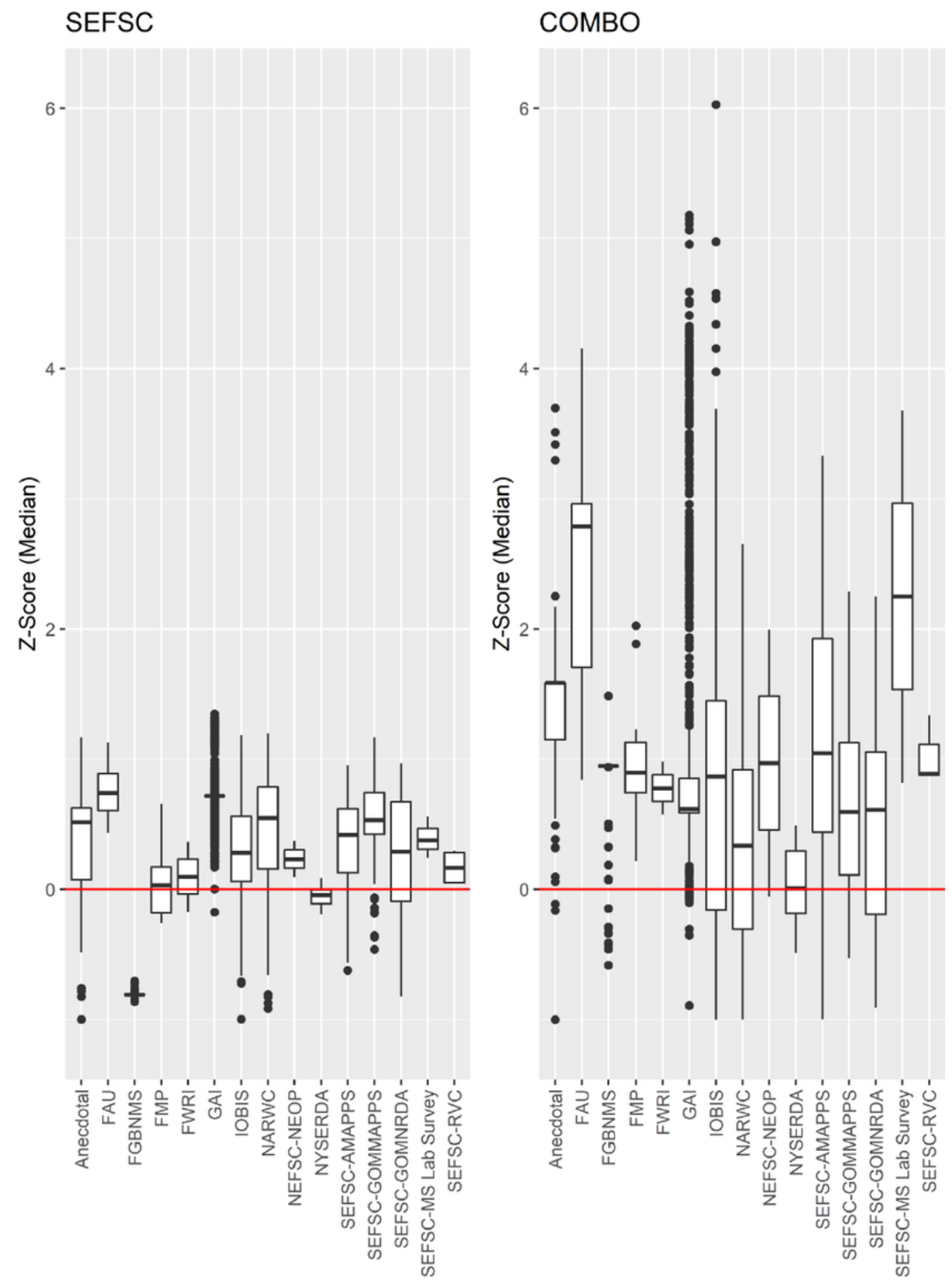

\section{Figure 7}

External validation of predictive utility of SEFSC and combined ("COMBO": SEFSC, NARWC, and NYSERDA) surveys species distribution models, showing predicted median Z-score standardized probabilities for independent observations for manta rays (see Table 1). Positive Z-scores (above red line) indicate consistency between independent observations and model predictions, with higher Z-scores indicative of greater predictive utility. 

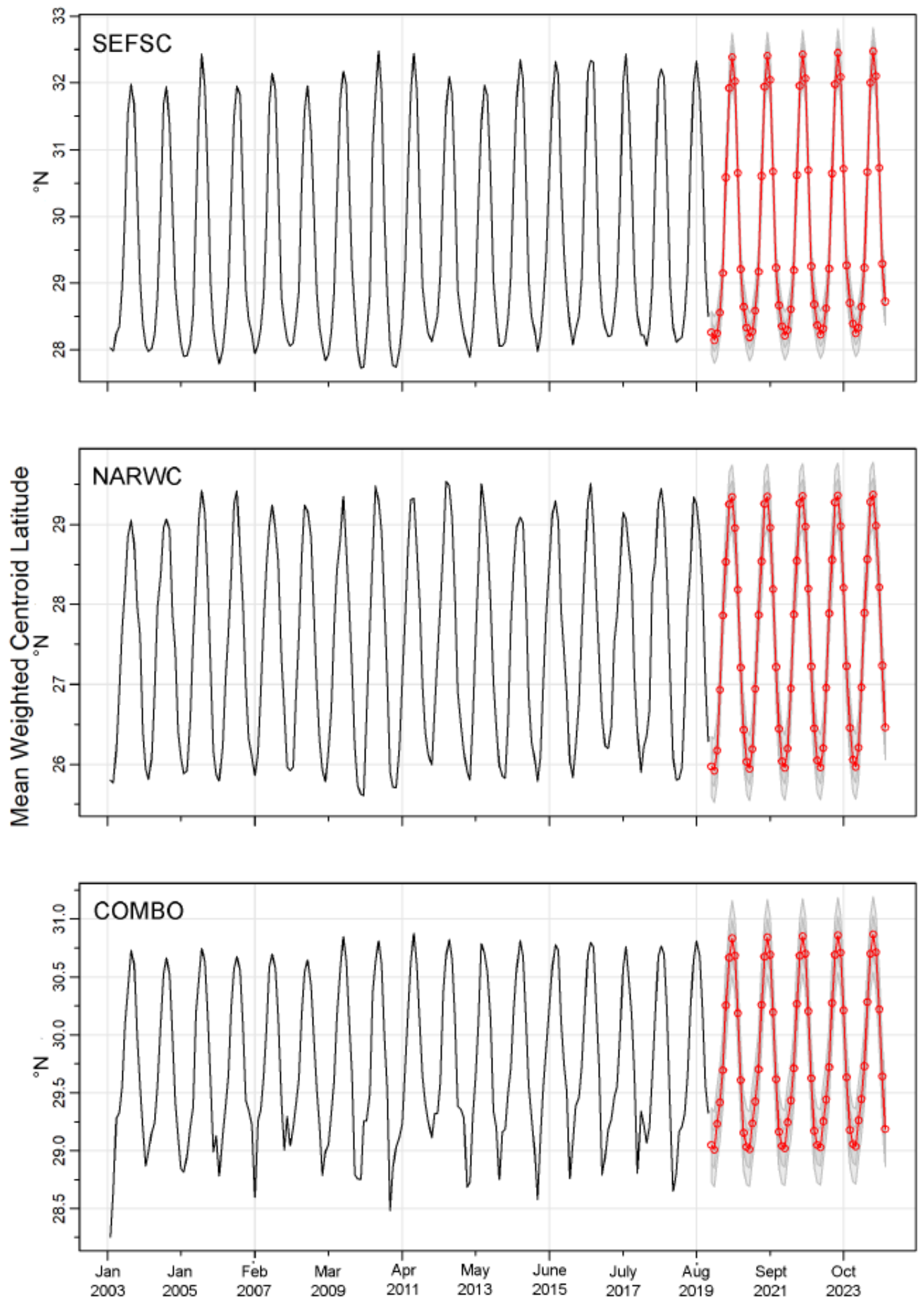

Figure 8

Time-series of predicted mean weighted latitudinal centroid for best-fitting manta ray species distribution models generated from SEFSC, NARWC, and combined surveys ("COMBO") from January 2003 to December 2019 with seasonal auto-regressive integrated moving average (SARIMA) mean (red) and \pm 1 and \pm 2 standard error (gray) forecasts for January 2020 to December 2024 . 


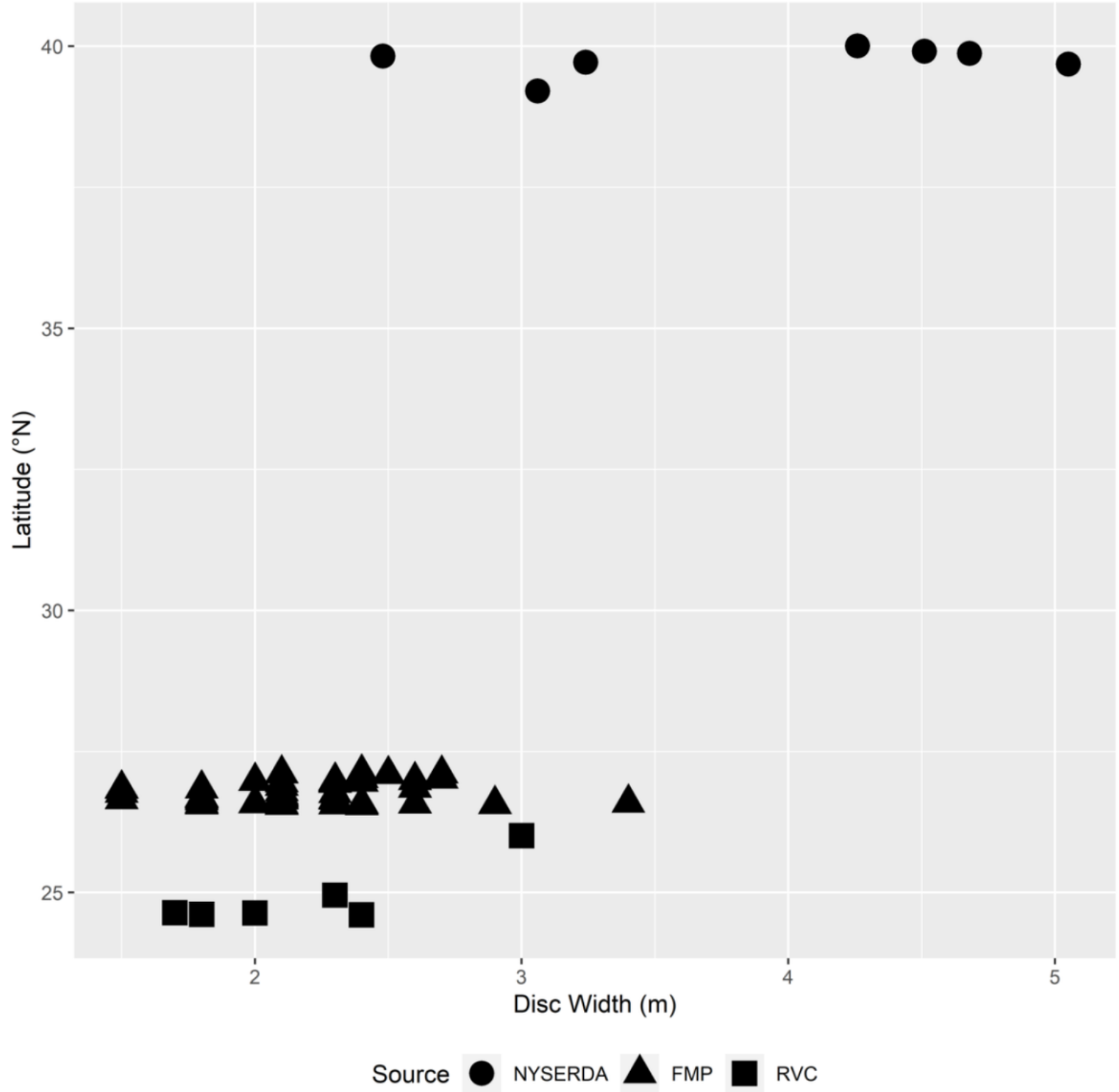

Figure 9

Estimated disc width $(\mathrm{m})$ for manta rays observed by National Marine Fisheries Service Reef Visual Census (RVC) divers, Florida Manta Project (FMP) snorkelers, and NYSERDA aerial digital photographic survey, by latitude.

\section{Supplementary Files}


This is a list of supplementary files associated with this preprint. Click to download.

- Prescombo20032019.mp4

- SupplementalFileReduced.pdf 